\title{
A família Myrtaceae na Floresta Nacional de Ipanema, Iperó, São Paulo, Brasil
}

\author{
The family Myrtaceae at National Forest of Ipanema, São Paulo, Brazil
}

\author{
Alan Teixeira da Silva ${ }^{1,2}$ \& Fiorella Fernanda Mazine ${ }^{1}$
}

\begin{abstract}
Resumo
Com aproximadamente 1.000 espécies e 23 gêneros ocorrentes no Brasil, Myrtaceae é uma das famílias mais representativas em levantamentos florísticos, principalmente em áreas de Cerrado e Mata Atlântica. A Floresta Nacional de Ipanema é ocupada predominantemente por Mata Atlântica e pequenas áreas de Cerrado. O objetivo deste trabalho foi contribuir para o conhecimento da família Myrtaceae na Floresta Nacional de Ipanema. Para isso foram realizadas coletas no período de setembro de 2012 a março de 2013 e consultadas as coleções dos seguintes herbários: SORO, ESA, IAC, SP, SPSF, UEC. Todo material coletado foi depositado na coleção do SORO. Após análise dos dados foram identificadas 23 espécies de Myrtaceae distribuídas em 6 gêneros: Eugenia (10 espécies), Myrcia (quatro espécies), Psidium (quatro espécies), Campomanesia (três espécies), Calyptranthes e Plinia (uma espécie cada gênero). Foram preparadas descrições, ilustrações e chaves analíticas de identificação das espécies.
\end{abstract}

Palavras-chave: Eugenia, Mata Atlântica, Myrcia, Myrteae, Taxonomia.

\begin{abstract}
With about 1.000 species and 23 genera occurring in Brazil, Myrtaceae is one of the most important families in floristic surveys, mainly in Cerrado and Atlantic Forest areas. The National Forest of Ipanema is occupied mostly by Atlantic Forest and small areas of Cerrado. The main objective of this work is to improve the knowledge of Myrtaceae in the National Forest of Ipanema. For this, field trips were made between September 2012 and March 2013 and the collections of the following herbaria were analyzed: SORO, ESA, IAC, SP, SPSF, UEC. All the collected specimens were deposited in SORO collection. After data analysis 23 species of Myrtaceae and 6 genera were found: Eugenia (10 species), Myrcia (four species), Psidium (four species), Campomanesia (three species), Calyptranthes (one species) and Plinia (one species). Descriptions, illustrations and keys of identification of the species were prepared.
\end{abstract}

Key words: Eugenia, Atlantic Forest, Myrcia, Myrteae, Taxonomy.

\section{Introdução}

A família Myrtaceae está amplamente distribuída pelo hemisfério sul, exibindo maior concentração de espécies nas regiões Neotropical e Australiana (Sytsma et al. 2004).

Myrtaceae compreende aproximadamente 4.630 espécies e 144 gêneros (Judd et al. 2009). No Brasil são conhecidas 1.034 espécies e 23 gêneros das quais 297 espécies e 17 gêneros têm ocorrência assinalada para o estado de São Paulo (BFG 2015).

Nos levantamentos florísticos e fitossociológicos realizados principalmente nas regiões Centro-Oeste, Sudeste e Sul do Brasil, Myrtaceae frequentemente se destaca como umas das famílias com maior riqueza de espécies (Leitão Filho 1982, 1993; Zipparro et al. 2005; Koch et al. 2014).

Myrtaceae está inserida na ordem Myrtales e abrange cerca de $40 \%$ do total das espécies da ordem (Souza \& Lorenzi 2013; Stevens 2012). As Myrtaceae têm passado por reclassificações intrafamiliares, apoiadas por análises moleculares e morfológicas, buscando um maior conhecimento das relações filogenéticas (Lucas et al. 2007, 2011).

\footnotetext{
1 Universidade Federal de São Carlos, Rodovia João Leme dos Santos (SP-264), Km 110, Bairro do Itinga, 18052-780, Sorocaba, SP, Brasil. 
No presente trabalho, foi realizado o levantamento de Myrtaceae na Floresta Nacional de Ipanema (FLONA Ipanema), local que já foi alvo de ações antrópicas. Albuquerque \& Rodrigues (2000) constataram, após um levantamento florístico da vegetação do morro de Araçoiaba, que Myrtaceae aparece representada por seis espécies, sendo suplantada apenas por Fabaceae (30 espécies) e Meliaceae (sete espécies).

O objetivo deste trabalho foi contribuir para o conhecimento sobre a família Myrtaceae na FLONA Ipanema promovendo seu estudo taxonômico através da análise e caracterização das espécies coletadas na área de estudo e identificadas nos principais herbários estaduais, apresentando descrições, chaves de identificação, dados de distribuição geográfica e ilustrações dos táxons.

\section{Material e Métodos}

A Floresta Nacional de Ipanema (antiga Fazenda Ipanema) está localizada no estado de São Paulo, abrange uma área de 5.179,93 ha e ocupa partes dos municípios de Iperó (ca. de $80 \%$ da área e sede administrativa), Araçoiaba da Serra e Capela do Alto (Fávero et al. 2007) (Fig. 1).

A FLONA Ipanema está inserida na parte leste da bacia sedimentar do Paraná, região de contato

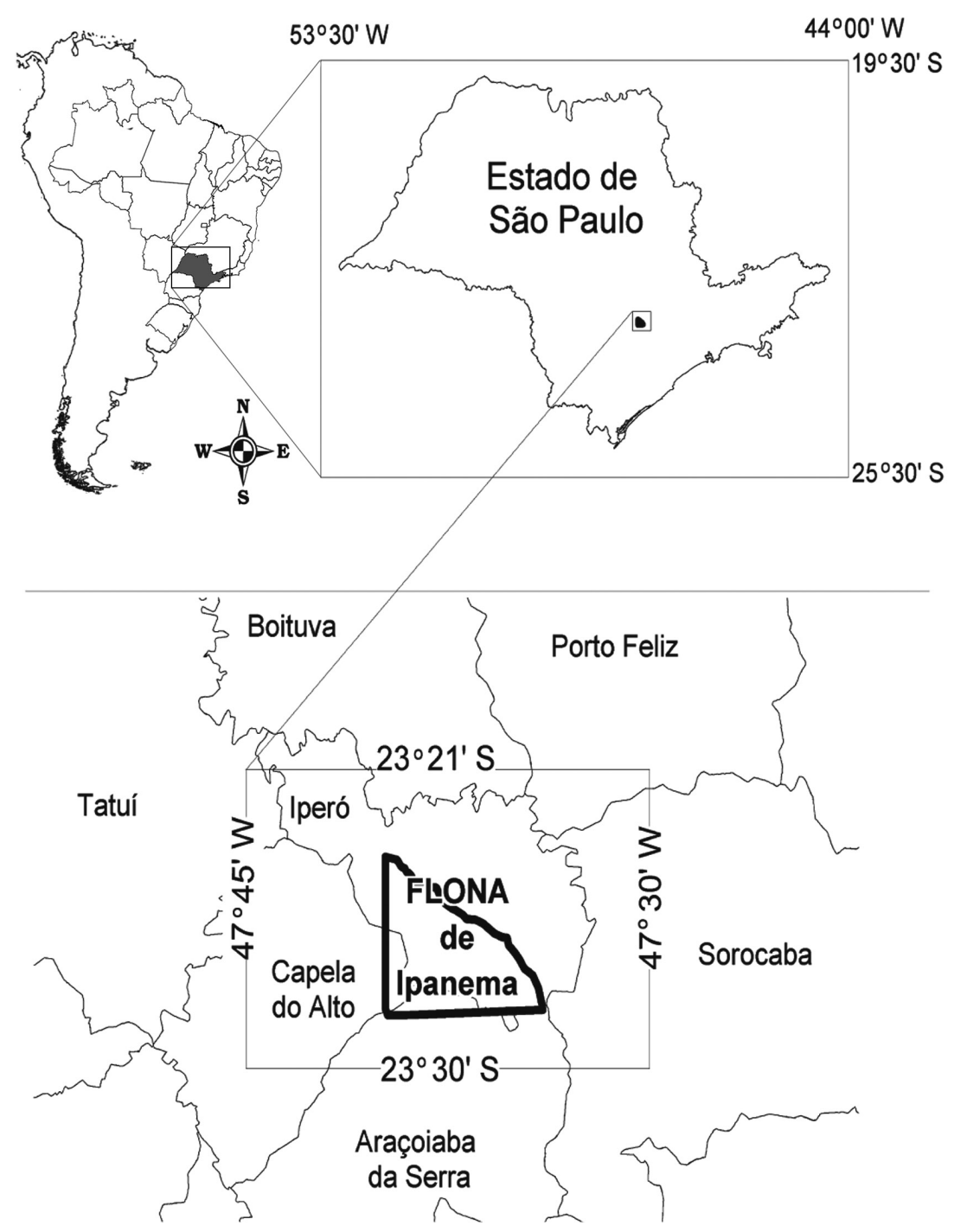

Figura 1 - Mapa de localização da Floresta Nacional de Ipanema. Fonte: Bataghin et al. 2010.

Figure 1 - Map of location of National Forest of Ipanema. Source: Bataghin et al. 2010. 
entre a Depressão Periférica Paulista e o Planalto Atlântico, zona da Depressão do Médio Tietê (Ross \& Moroz 1997). Também faz parte da bacia do Rio Sorocaba/Médio Tietê e das sub-bacias do Rio Ipanema e Ribeirões Iperó e do Ferro.

A altitude varia de $550 \mathrm{~m}$ até $971 \mathrm{~m}$ acima do nível do mar. A classificação climática de Köeppen para o local é: subtropical quente, constantemente úmido com inverno menos seco ( $\mathrm{Cfa}$ ), ao sul; e subtropical quente com inverno mais seco (Cwa), ao norte. A temperatura média varia de 24,2 a $17,2{ }^{\circ} \mathrm{Ce}$ umidade de $80,5 \%$ a $74,5 \%$, de acordo com a época do ano; a precipitação média anual é de $1.400 \mathrm{~mm}$, o mês mais chuvoso é janeiro com média de 226,7 mm e o mais seco é agosto com média de $34,9 \mathrm{~mm}$ (IBAMA 2003; Regalado 2005).

A FLONA Ipanema, segundo Regalado (2005), abrange os seguintes domínios vegetacionais e áreas de ocupação do solo: 1.878,23 ha de Floresta Estacional Semidecidual; 1.117,26 ha de floresta em regeneração; 125,04 ha de Cerradão; 133,55 ha de Cerrado (campo sujo); 303,45 ha de reflorestamento com espécies exóticas; 71,82 ha de reflorestamento com espécies nativas; 136,51 ha de várzea; 30,49 ha de corpos d'água; 923,71 ha com atividades agropecuárias; 41,35 ha de mineração; 43,21 ha de área urbana e 265,11 ha de afloramentos rochosos. Os locais com nuances de Floresta Ombrófila Densa e Mista não foram incluídos por Regalado (2005).

Para o levantamento foram realizadas 15 viagens de campo, entre os meses de setembro de 2012 e março de 2013. Os locais de coleta foram escolhidos de forma a abranger todos os tipos vegetacionais presentes na área; foram feitas caminhadas aleatórias em cada região e coletados todos os indivíduos de Myrtaceae em estado reprodutivo ou vegetativo.

Todo material botânico coletado foi identificado com base em literatura especializada, comparações com material tipo e auxílio de especialistas. O material coletado foi herborizado e está depositado no herbário SORO localizado na Universidade Federal de São Carlos, campus Sorocaba-SP.

Para a validação e identificação das espécies coletadas na FLONA Ipanema foi efetuada a consulta a coleções dos principais herbários do estado de São Paulo: SORO, ESA, IAC, SP, SPSF, UEC. A coleção do herbário SPF não foi consultada, tendo a curadoria daquele herbário informado a ausência de coletas da área de estudo.

As descrições taxonômicas e chaves dicotômicas de identificação das espécies e gêneros foram preparadas com base em materiais coletados em campo e consultados nos herbários. Descrições de caracteres reprodutivos, que não presentes nos espécimes coletados na área de estudo, foram complementados pela análise de materiais de outras localidades e denominados de material adicional.

A descrição floral de Campomanesia guaviroba foi realizada com base em Landrum (1986) devido a não coleta de espécimes em floração no local de estudo.

\section{Resultados e Discussão}

Na FLONA Ipanema foram identificadas 23 espécies de Myrtaceae distribuídas em seis gêneros: Eugenia (10 espécies), Myrcia (quatro espécies), Psidium (quatro espécies), Campomanesia (três espécies), Calyptranthes (uma espécie) e Plinia (uma espécie). O domínio fitogeográfico de maior ocorrência foi em Mata Atlântica, em áreas de Floresta Estacional Semidecidual.

\section{Tratamento taxonômico}

Myrtaceae Juss., Gen. Pl. 322 (1789).

Arbustos até árvores. Casca normalmente esfoliante. Folhas opostas, glabras ou com indumento de tricomas simples, unicelulares ou dibraquiados, margem inteira, venação peninérvea, geralmente com a nervura primária proeminente, nervuras secundárias unidas por uma ou duas nervuras marginais paralelas a borda ou formando arcos; glândulas translúcidas visíveis ao olho nu ou não. Flores brancas, solitárias ou em dicásio, racemo, panícula, fascículo ou glomérulo, bissexuadas, diclamídeas, raramente com pétalas de tamanho reduzido ou abortadas, actinomorfas, hipanto bem desenvolvido; cálice (3)4-5(6)-mero, dialissépalo, frequentemente persistente no fruto; corola (3)4-5(6)-mera, dialipétala; androceu multiestaminado, dialistêmone, exsertos, filetes filiformes, anteras globulares, rimosas e bitecas; gineceu com o ovário ínfero, gamocarpelar, de bi a multilocular, dois a muitos óvulos por lóculo. Frutos bagas. Sementes com embrião de cotilédones vestigiais até grandes e carnosos; hipocótilo pequeno a alongado.

Landrum (1986) e Landrum \& Kawasaki (1997) propuseram a seguinte classificação para os tipos de embrião: mircioide - cotilédones foliáceos e hipocótilo desenvolvido; eugenioide - cotilédones carnosos (fundidos ou não) e o hipocótilo vestigial ou ausente; e mirtoide - com hipocótilo desenvolvido (espiral ou em forma de "C") e cotilédones pequenos ou vestigiais (Fig. 2). 


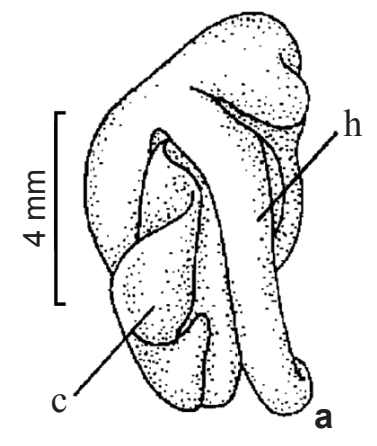

c: cotilédone h: hipocótilo
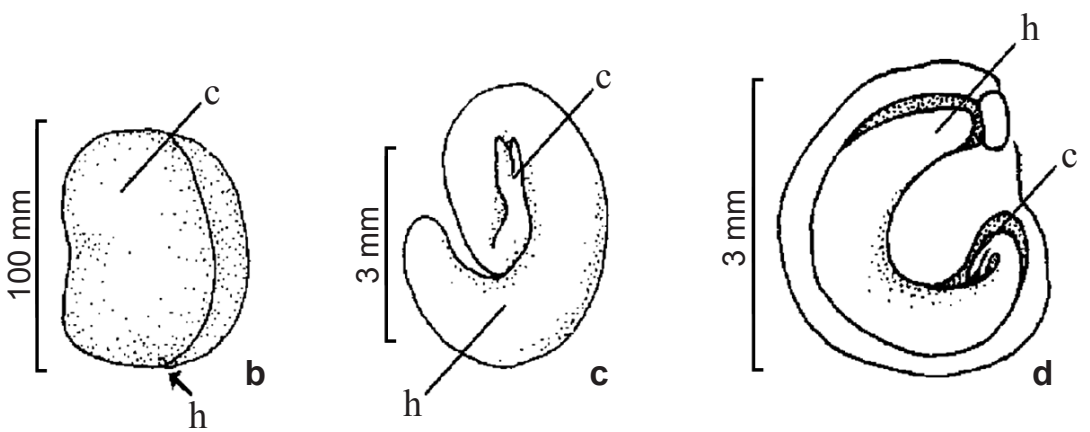

Figura 2 - a. embrião mircióide, cotilédones foliáceos e hipocótilo desenvolvido; b. embrião eugenióide, cotilédones carnosos e o hipocótilo vestigial ou ausente; c. embrião mirtóide, hipocótilo desenvolvido em espiral e cotilédones pequenos ou vestigiais; d. embrião mirtóide, hipocótilo em forma de " $\mathrm{C}$ ". (Adaptado de Lucas et al. 2007).

Figure 2 - a. myrcioid embryo, leafy cotyledons and developed hypocotyl; b. eugenioid embryo, fleshy cotyledons and small or missing hypocotyl; c. myrtoid embryo, developed spiral-shaped hypocotyl and small or missing cotyledons; d. myrtoid embryo, C-shaped hypocotyl. (Adapted of Lucas et al. 2007).

\section{Chave geral para identificação de Myrtaceae ocorrentes na Floresta Nacional de Ipanema. Iperó - SP:}

1. Flores reunidas em panículas

1'. Flores solitárias ou reunidas em glomérulos, racemos, cimeiras, dicásios ou fascículos .

2. Ramos jovens com ramificação dicotômica; cálice abrindo-se na antese por uma caliptra

Calyptranthes concinna

2'. Ramos jovens sem ramificação dicotômica; cálice com lobos regulares ou irregulares na antese sem formação de caliptra

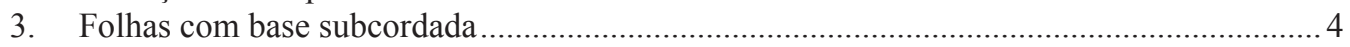

3'. Folhas com base atenuada, cuneada ou aguda

4. Folhas discolores, nervura marginal em arcos, de 1-4 mm da margem; pedúnculo da inflorescência com indumento castanho-amarelado.

Myrcia uberavensis

4'. Folhas concolores, nervura marginal em arcos, de 1-2 mm da margem; pedúnculo da inflorescência glabro

Myrcia variabilis

5. Ramos jovens e folhas com indumento denso, amarelo-palha em toda a superfície, sensível ao tato; pedúnculo da inflorescência sem pontuações translúcidas; frutos maduros pretos

Myrcia tomentosa

5'. Ramos jovens com indumento argênteo não sensível ao tato; folhas glabras ou com tricomas isolados, argênteos; pedúnculo da inflorescência com pontuações translúcidas; frutos maduros roxos.

Myrcia multiflora

6. Folhas sempre com duas nervuras marginais ............................................ 7

6'. Folhas com uma nervura marginal ...................................................... 9

7. Folhas com ambas as nervuras marginais paralelas à borda; flores reunidas em glomérulos caulifloros Plinia cauliflora

7'. Folhas com nervura marginal interna em arcos; flores solitárias ou reunidas em glomérulos ramifloros, racemos, cimeiras, dicásios ou fascículos.... 
8. Folhas com lâminas elípticas, lanceoladas ou oblanceoladas; discolores; flores reunidas em racemos. Eugenia florida

8'. Folhas com lâminas ovais, raramente obovais ou largo-elípticas; concolores; flores em cimeiras

9. Folhas, na face abaxial, com tufos de tricomas entre as nervuras central e secundária. 10

9'. Folhas, na face abaxial, sem tufos de tricomas entre as nervuras central e secundária 11 10. Folhas com margem ondulada Campomanesia guaviroba 10'. Folhas com margem plana Campomanesia neriiflora

11. Lâminas foliares com indumento amarelo-palha presente sobre todas as nervuras, em ambas as faces Campomanesia guazumifolia

11'. Lâminas foliares glabras ou se com indumento, este não concentrado sobre todas as nervuras .12

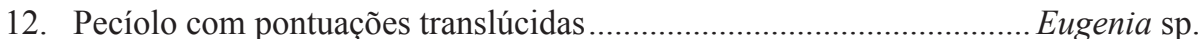
12'. Pecíolo sem pontuações translúcidas 13

13. Folhas com margem revoluta apenas na região basal Psidium sp.

13'. Folhas com a margem totalmente revoluta ou plana

14. Frutos globoso-costados. . .14

14'. Frutos globosos não costados Eugenia uniflora

15. Flores reunidas em dicásios, frutos piriformes

Eugenia pyriformis

15'. Flores solitárias ou reunidas em glomérulos ramifloros ou fascículos; frutos globosos

16. Flores em glomérulos ramifloros Eugenia pluriflora

16'. Flores solitárias ou em fascículos 17

17. Ramos jovens quadrangulares ou retangulares

Psidium guajava

17'. Ramos jovens cilíndricos ou achatados nas partes terminais .

18. Ramos jovens achatados nas partes terminais

18'. Ramos jovens cilíndricos nas partes terminais .21

19. Folhas com 7 a 9 pares de nervuras secundárias. Psidium guineense

19'. Folhas com 10 a 25 pares de nervuras secundárias. 20

20. Lâminas foliares com pontuações translúcidas visíveis a olho nu, subcoriáceas ou coriáceas, margem plana; frutos com indumento argênteo.

Eugenia francavilleana

20'. Lâminas foliares com pontuações translúcidas visíveis apenas em lupa, cartáceas, margem ondulada; frutos glabros. Eugenia cerasiflora

21. Folhas cartáceas; flores terminais em nós bracteados

Eugenia ligustrina

21’. Folhas coriáceas; flores em nós desprovidos de brácteas 
22. Folhas com pecíolo enrugado, 2 a $3 \mathrm{~mm}$ de comprimento, nervura marginal paralela a borda

Eugenia punicifolia

22'. Folhas com pecíolo liso, 5 a $7 \mathrm{~mm}$ de comprimento, nervura marginal em arcos.

Psidium cattleianum

1. Calyptranthes concinna DC., Prodr. 3: 258. 1828.

Fig. 3a

Arvoretas de 1,5-3,0 m de alt.; ramos jovens com ramificação dicotômica, castanho-esverdeados com indumento castanho-amarelado, cilíndricos nas partes terminais, sem pontuações translúcidas; ramos adultos castanho-amarronzados, ritidoma descamante acinzentado, glabros. Folhas com pecíolo castanho-esverdeado, glabro ou com indumento castanho-amarelado na parte convexa, canaliculado, de 3-5 $\mathrm{mm}$ de compr., sem pontuações translúcidas; lâminas com 45-70 $\times$ 18-30 mm, obovais, elípticas, oblanceoladas ou lanceoladas; ápice agudo, base aguda ou atenuada; face adaxial glabra, face abaxial com esparso indumento castanho-amarelado localizado, principalmente, na região da nervura central, discolores, cartáceas; margem revoluta ou não revoluta, plana; nervura central sulcada na face adaxial e saliente na face abaxial, 15-30 pares de nervuras secundárias, nervura marginal em arcos pouco acentuados, de 0,5-1,0 $\mathrm{mm}$ da margem; pontuações translúcidas visíveis apenas em lupa, salientes em ambas as faces. Flores, 2-3, em panículas de dicásios axilares; pedúnculo da inflorescência verde-claro, 20-40 $\mathrm{mm}$ de compr., indumento castanho-amarelado, sem pontuações translúcidas; cálice abrindo-se na antese por uma caliptra; ovário com 2 lóculos, dois óvulos por lóculo, placentação axilar. Bagas globosas, não costadas, de $5-6 \mathrm{~mm}$ de diâm., indumento esparso, castanho-amarelado; $2 \mathrm{~mm}$ de diâm. de abertura da caliptra; 1-2 sementes por fruto; testa membranácea; embrião mircioide.

Material examinado: $23^{\circ} 26^{\prime} 31.86^{\prime \prime} \mathrm{S}, 47^{\circ} 35^{\prime} 35.76^{\prime \prime O}$, 22.XI.2012, A.T. Silva \& L.E.G.D. Nogueira 10 (SORO); 2326'32.41”'S, 47³5’35.41”O, 22.XI.2012, A.T. Silva \& L.E.G.D. Nogueira 12 (SORO); $23^{\circ} 26^{\prime} 32.43^{\prime \prime S}, 47^{\circ} 35^{\prime} 35.48^{\prime \prime}$ 'O, 22.XI.2012, A.T. Silva \& L.E.G.D. Nogueira 14 (SORO); 2326'32.71"S, 47'35'35.16"O, 22.XI.2012, A.T. Silva \& L.E.G.D. Nogueira 19 (SORO); $23^{\circ} 26^{\prime} 34.75^{\prime \prime}$ 'S, 47³5'24.30”'O, 22.XI.2012, A.T. Silva \& L.E.G.D. Nogueira 22

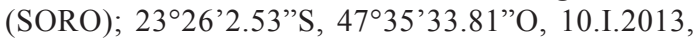
fl. e fr., A.T. Silva 28 (SORO); 2326'23.46”'S, 47'35'35.26”'O, 31.I.2013, fl., A.T. Silva 42 (SORO); $23^{\circ} 26^{\prime} 31.61^{\prime \prime S}, 47^{\circ} 35^{\prime} 36.00^{\prime}$ 'O, 31.I.2013, fl., A.T.
Silva 44 (SORO); $23^{\circ} 25^{\prime} 56.70^{\prime \prime} \mathrm{S}, 47^{\circ} 35^{\prime} 33.94$ ”O, 21.II.2013, fl., A.T. Silva 52 (SORO); Fazenda Ipanema, porteira da Fepasa, 4.XII.1998, fl., A.M.G.A. Tozzi et al. 368 (UEC).

Segundo BFG (2015) e Govaerts et al. (2008) a espécie ocorre nos remanescentes de Mata Atlântica do estado de São Paulo até o nordeste da Argentina.

Na FLONA Ipanema a espécie é abundante e foi encontrada em locais variados de Floresta Estacional Semidecidual, porém, observou-se uma preferência por áreas ensolaradas e/ou próximo a corpos hídricos.

2. Campomanesia Ruiz \& Pav., Fl. Peruv. Prodr. 72, t. 13. 1794.

Fig. 3b,c

Arvoretas ou árvores; sem ramificação dicotômica. Bractéolas decíduas na antese. Flores axilares ou surgindo junto com as brotações novas; solitárias, 5-meras; pétalas presentes; cálice fechado ou levemente aberto no botão floral com lobos individualizados; ovário com 9-14 lóculos, parede do lóculo fortemente glandular no fruto maduro aparentando uma falsa testa; 4-20 óvulos por lóculo, dispostos em duas fileiras com placentação central. Bagas geralmente coroadas pelo cálice íntegro ou não, ou por cicatriz circular; numerosas sementes por fruto; testa membranácea; embrião mirtoide com hipocótilo em espiral, cotilédones reduzidos.

Campomanesia pode ser facilmente reconhecida pelo ritidoma que é escamoso ou papiráceo, nunca liso, como o que ocorre nas goiabeiras. O número de lóculos, na sua maioria, são maiores que quatro. As sementes apresentam testa fina e delicada protegida pela parede do ovário, fortemente glandular. (Landrum 1986; Lima et al. 2011).

Segundo Landrum (1986) o gênero ocorre desde o norte da Argentina até Trinidad Tobago e desde a costa leste do Brasil até a Cordilheira dos Andes (Peru, Colômbia e Equador). No Brasil, BFG (2015) citam 41 espécies (32 endêmicas) que ocorrem principalmente na Mata Atlântica e Cerrado, havendo também registros para a Amazônia e Caatinga. Na FLONA Ipanema ocorrem três espécies. 


\subsection{Campomanesia guaviroba (DC.) Kiaersk.,} Enum. Myrt. Bras. 8. 1893.

Fig. 3b

Arvoretas ou árvores de 1,5-5,0 m de alt.; ramos jovens castanho-amarelados, indumento ferruginoso e curto, achatados nas partes terminais, com pontuações translúcidas; ramos adultos castanho-amarelados, glabros. Folhas com pecíolo verde e o mesmo tipo de indumento dos ramos novos, canaliculado, de 5-6 $\mathrm{mm}$ de compr., sem pontuações translúcidas; lâminas com 30-70 $\times 10-30 \mathrm{~mm}$, ovais ou oblanceoladas; ápice e base atenuados; face adaxial com indumento castanho-amarelado e curto, na região da nervura central e, ocasionalmente, esparso nas nervuras secundárias, face abaxial com tufos de indumento castanho-amarelado na axila entre as nervuras central e secundárias, ligeiramente discolores, membranáceas até subcoriáceas; margem revoluta, ondulada; nervura central sulcada na face adaxial e saliente na face abaxial, 4-9 pares de nervuras secundárias, muito salientes, mais claras que a cor do limbo, nervura marginal em arcos, de 1-4 mm da margem; pontuações translúcidas visíveis apenas em lupa, saliente na face abaxial. Flores solitárias; pedúnculo com 3-25 mm de compr., indumento presente; sépalas 5 , largo triangulares ou arredondadas, $2,5-6,0 \times 1,5-3,0$ $\mathrm{mm}$, presença de pontuações translúcidas; pétalas suborbiculares, 5-9 mm de diâmetro, presença de pontuações translúcidas. Bagas globosas, não
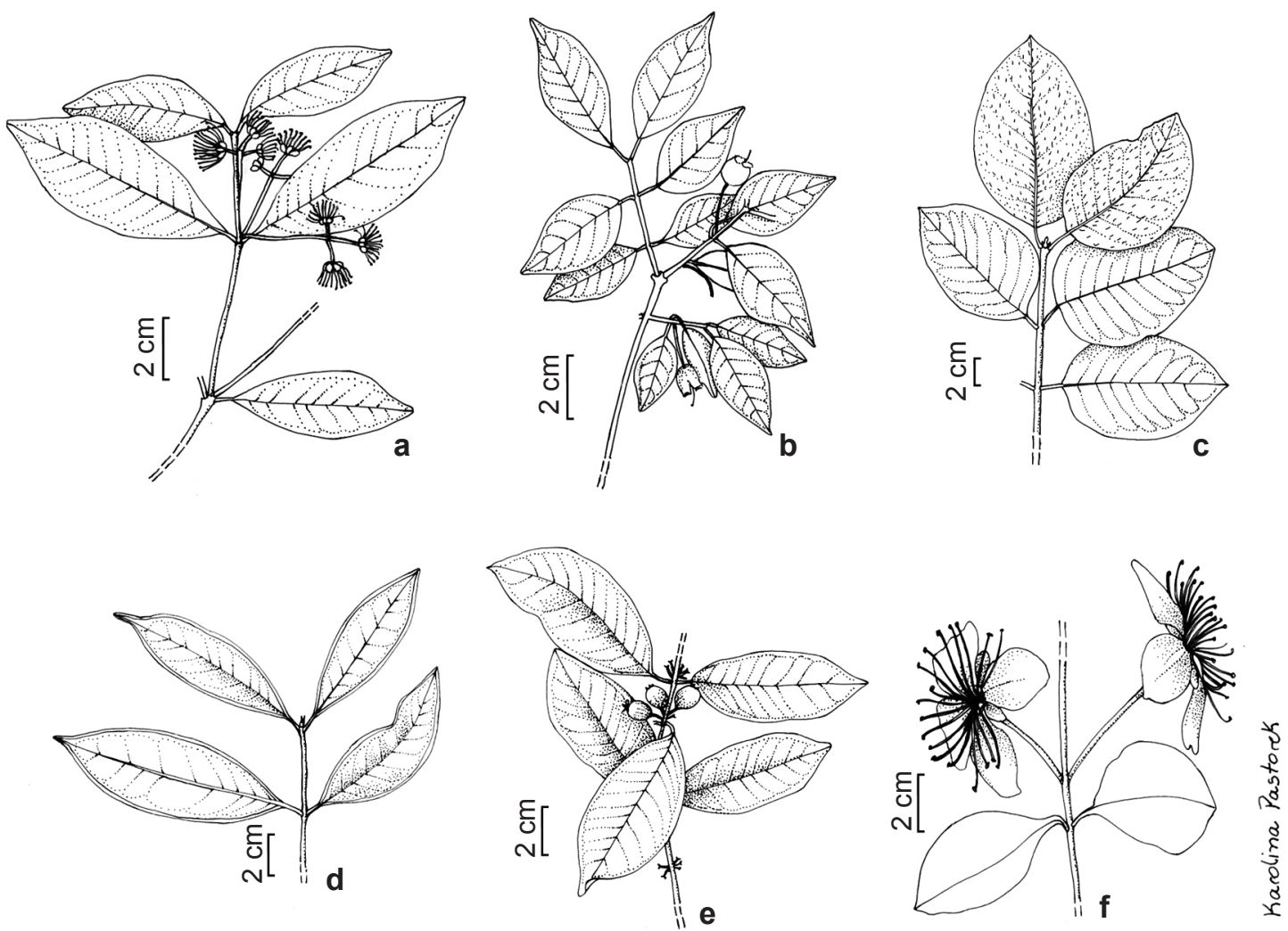

Figura 3 - a. Calyptranthes concinna - ramo florífero. b. Campomanesia guaviroba - ramo frutífero. c. Campomanesia guazumifolia - ramo com denso e longo indumento concentrado sobre todas as nervuras foliares. d. Eugenia florida - folhas com duas nervuras marginais, o primeiro par de nervuras secundárias não confluentes com as demais. e. Eugenia francavilleana - ramo frutífero. f. Eugenia ligustrina - ramo florífero (a. A.T. Silva 28; b. A.T. Silva 32; c. A.T. Silva \& L.E.G.D. Nogueira 59; d. A.T. Silva 29; e. M.F. Casali 97; f. A.T. Silva 7). Figure 3 - a. Calyptranthes concinna - flowering branch. b. Campomanesia guaviroba - fruiting branch. c. Campomanesia guazumifolia - branch with dense and long hairs placed mainly around the veins of the leaves. d. Eugenia florida - leaves with two marginal veins, the first pair of secondary veins do not converge with the others. e. Eugenia francavilleana - fruiting branch. f. Eugenia ligustrina - flowering branch (a. A.T. Silva 28; b. A.T. Silva 32; c. A.T. Silva \& L.E.G.D. Nogueira 59; d. A.T. Silva 29; e. M.F. Casali 97; f. A.T. Silva 7). 
costadas, lisas, amarelas ou alaranjadas quando maduras, sem pontuações translúcidas, de 10-30 $\mathrm{mm}$ de diâm., com curto e denso indumento ferrugíneo, com sépalas persistentes; pedúnculo castanho-amarelado, $15 \mathrm{~mm}$ de compr., com o mesmo tipo de indumento presente nos frutos. Material examinado: 20.XII.2008, fr., M.F. Casali 202 (SORO); $23^{\circ} 25^{\prime} 45.94^{\prime \prime} \mathrm{S}, 4^{\circ} 35^{\prime} 57.94^{\prime \prime} \mathrm{O}$, 10.I.2013, fr., A.T. Silva 32 (SORO); $23^{\circ} 26^{\prime} 6.40^{\prime \prime}$ 'S, 47³5'52.90"O, 17.I.2013, fr., A.T. Silva 35 (SORO); 23026'00.9"'S, 47 36'31.4"O, 24.I.2013, A.T. Silva 39 (SORO); 2326'00.9"'S, 47 36'31.4”'O, 24.I.2013, A.T. Silva 41 (SORO); $23^{\circ} 25^{\prime} 7.37^{\prime \prime} \mathrm{S}, 4^{\circ} 35^{\prime} 34.22^{\prime \prime} \mathrm{O}$, 14.III.2013, A.T. Silva 68 (SORO).

Segundo Landrum (1986) e Govaerts et al. (2008) a espécie ocorre desde o sudeste do Brasil até o nordeste da Argentina (região das Missões). BFG (2015) citam a ocorrência da espécie em áreas de Mata Atlântica e Cerrado, nos estados do Amazonas, Bahia e Distrito Federal.

Na FLONA Ipanema a espécie é abundante e foi encontrada em diversos locais de Floresta Estacional Semidecidual.

No local de estudo, C. guaviroba pode ser reconhecida pelos tricomas nas axilas entre a nervura central e secundárias, e frutos de casca lisa. Lima et al. (2011) mencionam a considerável variação morfológica ocorrente na espécie, principalmente com relação ao tamanho de folhas e frutos, fato que também foi observado nos espécimes coletados.

2.2. Campomanesia guazumifolia (Cambess.) O.Berg, Fl. Bras. (Martius) 14(1): 457 (-458). 1857.

Fig. 3c

Arvoretas ou árvores de 1,5-6,0 m de alt.; ramos jovens e adultos castanho-amarelados, denso e longo indumento amarelo-palha, levemente achatado nas partes terminais, sem pontuações translúcidas. Folhas com pecíolo castanho-amarelado, mesmo tipo de indumento dos ramos, canaliculado, de $8-12 \mathrm{~mm}$ de compr., sem pontuações translúcidas; lâminas de 75-125 × 45-75 mm ovais ou elípticas; ápice obtuso, cuneado ou arredondado, base obtusa ou arredondada; face adaxial e abaxial com o mesmo tipo de indumento dos ramos, densos e concentrados sobre todas as nervuras, discolores, subcoriáceas; margem não revoluta, plana; nervura central sulcada na face adaxial e saliente na face abaxial, de 15-20 pares de nervuras secundárias, na face abaxial castanhoamareladas, proeminentes, nervura marginal em arcos incompletos, no mínimo $0,5 \mathrm{~mm}$ da margem; pontuações translúcidas visíveis apenas em lupa, salientes em ambas as faces. Flores solitárias; pedúnculo com $2-3 \mathrm{~mm}$ de compr., indumento presente, sem pontuações translúcidas; sépalas 6, 5-8 × 2-6 mm, presença de pontuações translúcidas, indumento argênteo; pétalas $6,16-19 \times 15-19 \mathrm{~mm}$, presença de pontuações translúcidas; estames amarelados. Bagas globosas, não costadas, lisas, verdeamarelo quando madura, $15 \mathrm{~mm}$ de diâm., longo e denso indumento amarelo-palha; sépalas persistentes.

Material examinado: $23^{\circ} 26^{\prime} 2.01^{\prime \prime} \mathrm{S}, 4^{\circ} 36^{\prime} 32.60^{\prime \prime} \mathrm{O}$, 28.II.2013, A.T. Silva \& L.E.G.D. Nogueira 56 (SORO); $23^{\circ} 26^{\prime} 2.38^{\prime \prime} \mathrm{S}, 4^{\circ} 36^{\prime} 32.31^{\prime \prime} \mathrm{O}, 28 . \mathrm{II} .2013$, fr., A.T. Silva \& L.E.G.D. Nogueira 59 (SORO).

Material adicional examinado: BRASIL, SÃO PAULO, Campinas, Subdistrito de Sousas, 29.X.1996, fl., K. Santos 136 (UEC).

Segundo Landrum (1986) e Govaerts et al. (2008) a espécie ocorre desde o sudeste do Brasil, Paraguai até o nordeste da Argentina. BFG (2015) citam a espécie também para o estado da Bahia, nos domínios: Caatinga, Mata Atlântica e Cerrado. Na FLONA Ipanema, a espécie foi encontrada apenas próximo da entrada da trilha da Pedra Santa.

Campomanesia guazumifolia apresenta algumas características típicas que a torna distinta das demais na área de estudo como: tronco com casca suberosa que se desprende em várias camadas, folhas com nervuras secundárias salientes e cobertas de tricomas.

2.3. Campomanesia neriiflora (O.Berg) Nied. Nat. Pflanzenfam. [Engler \& Prantl] 3(Abt. 7, lief. 81): 73.1893.

Árvores; ramos jovens marrom-escuros, curto indumento amarelado, ligeiramente achatado nas partes terminais, sem pontuações translúcidas; ramos adultos acinzentados e glabros. Folhas com pecíolo canaliculado, de $5-10 \mathrm{~mm}$ de compr., castanho-amarronzado e o mesmo tipo de indumento dos ramos novos, sem pontuações translúcidas; lâminas de 70-90 × 35-40 mm, elípticas ou raramente ovais; ápice acuminado, base aguda ou raramente atenuada; face adaxial glabra ou esparso indumento castanho-amarelado nas regiões da nervura central e secundárias, e face abaxial com tufos de indumento castanhoamarelado nas axilas entre as nervuras central e secundária, concolores, membranáceas; margem 
revoluta, plana; nervura central sulcada na face adaxial e saliente na face abaxial, de 6-9 pares de nervuras secundárias, salientes e amareladas, nervura marginal em arcos, de 1-5 mm da margem; pontuações translúcidas visíveis a olho nu, saliente na face abaxial. Flores solitárias; pedúnculo castanho-amarronzado, de 35-40 mm de compr., com curto indumento amarelado, sem pontuações translúcidas; sépalas $5,5 \times 5 \mathrm{~mm}$, irregulares, presença de pontuações translúcidas, indumento argênteo; pétalas 5, 20-23 × $20 \mathrm{~mm}$, presença de pontuações translúcidas. Bagas globosas, não costadas, enrugadas, verdes quando imaturas, pretas quando herborizadas, $10 \mathrm{~mm}$ de diâm., com esparso e curto indumento amarelado; sépalas persistentes.

Material examinado: porteira da FEPASA, $520 \mathrm{~m}$, 4.XII.1998, fr., A.M.G.A. Tozzi et al. 385 (UEC).

Material adicional examinado: BRASIL, SÃO PAULO, Campinas, Reserva Florestal Santa Genebra, 8.X.1984, fl., G. L. Webster \& J. Y. Tamashiro 25376 (UEC).

A espécie ocorre em São Paulo e Paraná, em fragmentos de Mata Atlântica (Landrum 1986; BFG 2015).

Vegetativamente $C$. neriiflora é muito similar a C. guaviroba, sendo distinta pelos frutos enrugados (vs.: frutos lisos em C. guaviroba).

\section{Eugenia L., Sp. Pl. 1: 470. 1753.}

Figs. 3d,e,f; 4a,b,c,d

Arvoretas a árvores; sem ramificação dicotômica. Bractéolas persistentes ou não na antese. Flores axilares, tetrâmeras, terminais ou em nós bracteados; solitárias ou reunidas em racemos, cimeiras, fascículos, glomérulos ramifloros ou dicásios; pétalas presentes; cálice fechado ou levemente aberto no botão com lobos individualizados; 2-(3) lóculos por ovário; 2numerosos óvulos por lóculo; placentação axilar. Bagas coroadas pelas sépalas; 1-2-(3) sementes por fruto; testa membranácea a crustada; embrião eugenioide com cotilédones fundidos formando uma massa sólida, hipocótilo reduzido.

Eugenia é o gênero com maior número de representantes da tribo Myrteae com mais de 1000 espécies e de distribuição Pantropical (Govaerts et al. 2008). São 388 espécies registradas em todo território nacional, sendo 302 endêmicas. Ocorre principalmente na Mata Atlântica, mas também há registros em todos os outros domínios vegetacionais nacionais (BFG 2015). Na FLONA Ipanema ocorrem 10 espécies.
3.1. Eugenia cerasiflora Miq., Linnaea 22: 793. 1850.

Árvore, altura não determinada; ramos jovens esbranquiçados, glabros, achatados nas partes terminais, sem pontuações translúcidas; ramos adultos castanho-amarelados e glabros. Folhas com pecíolo amarelado, glabro, enrugado, canaliculado, de 5-9 mm de compr., sem pontuações translúcidas; lâminas de 50-70 × 35-50 mm, elípticas ou raramente obovais; ápice cuspidado ou atenuado, base atenuada, obtusa ou aguda; face adaxial e abaxial glabra, discolores, cartáceas; margem revoluta, ondulada; nervura central amarelada, sulcada na face adaxial e muito saliente na face abaxial, de 18-25 pares de nervuras secundárias, nervura marginal em arcos, de $1-3 \mathrm{~mm}$ da margem; pontuações translúcidas visíveis apenas em lupa, saliente na face abaxial. Flores solitárias ou em fascículos, axilares; pedúnculo castanhoavermelhado, de 5-15 $\mathrm{mm}$ de compr., tricomas isolados castanho-amarelados, sem pontuações translúcidas; sépalas 4, 1,5-3,0 × 0,5-3,0 mm; pétalas $4,9 \times 5 \mathrm{~mm}$. Bagas globosas, não costadas, marrom-avermelhadas quando herborizada, 10 $\mathrm{mm}$ de diâm., glabras, presença de pontuações translúcidas.

Material examinado: encosta e morro, IX.1997, fr., G.B. Albuquerque et al. 1800 (ESA).

Material adicional examinado: BRASIL, SÃO PAULO, São José dos Campos, Reserva Florestal da Boa Vista, 6.III.1986, fl., A. F. Silva \& Capellari Jr. 1.387 (UEC).

Segundo Govaerts et al. (2008) e BFG (2015) a espécie é endêmica do Brasil com ocorrência na Mata Atlântica, Cerrado e Caatinga, desde Sergipe até Santa Catarina.

Na FLONA Ipanema foi encontrada em encosta e topo de morro, a $805 \mathrm{~m}$ de altitude. As principais características de E. cerasiflora são seus ramos jovens achatados na parte terminal, folhas elípticas com margem ondulada e revoluta.

\subsection{Eugenia florida DC., Prodr. 3: 283. 1828.}

Fig. 3d

Arvoretas ou árvores de $2-5 \mathrm{~m}$ de alt.; ramos jovens variando de castanho-amarelado até castanho-avermelhado, curto indumento castanhoamarelado, achatados nas partes terminais, presença de pontuações translúcidas; ramos adultos castanho-amarelados ou acinzentados, glabros, presença de pontuações translúcidas. Folhas com pecíolo castanho-esverdeado, curto indumento castanho-amarelado, canaliculado, de 5-10 mm 
de compr., sem pontuações translúcidas; lâminas de $70-150 \times 25-55 \mathrm{~mm}$, arroxeadas quando jovem, elípticas, lanceoladas ou oblanceoladas; ápice acuminado ou caudado, base atenuada, aguda ou obtusa; face adaxial com curto e esparso indumento castanho-amarelado podendo haver maior concentração na região da nervura central, e face abaxial glabra ou com o mesmo tipo de indumento da face adaxial, discolores, subcoriáceas; margem revoluta na base, plana; nervura central sulcada na face adaxial e saliente na face abaxial, de 12-20 pares de nervuras secundárias, duas nervuras marginais, a interna em arcos, de 2-4 $\mathrm{mm}$ da margem, a externa se origina do primeiro par de nervuras secundárias e se alonga paralelamente por toda a margem; pontuações translúcidas levemente escurecidas, visíveis apenas em lupa, sulcada na face adaxial e saliente na face abaxial. Flores em racemos com pedúnculos de 10-15 mm de compr., pedicelos de 2-6 mm de compr., ambos castanho amarelados, tricomas isolados castanho-amarelados, com pontuações translúcidas; sépalas $4,1,5 \times 1,5$ $\mathrm{mm}$, arredondadas, com pontuações translúcidas; pétalas $4,4 \times 3 \mathrm{~mm}$, presença de pontuações translúcidas. Bagas globosas, não costadas, castanho-avermelhadas quando maduras, 5-10 mm de diâm., com indumento castanho-amarelado.
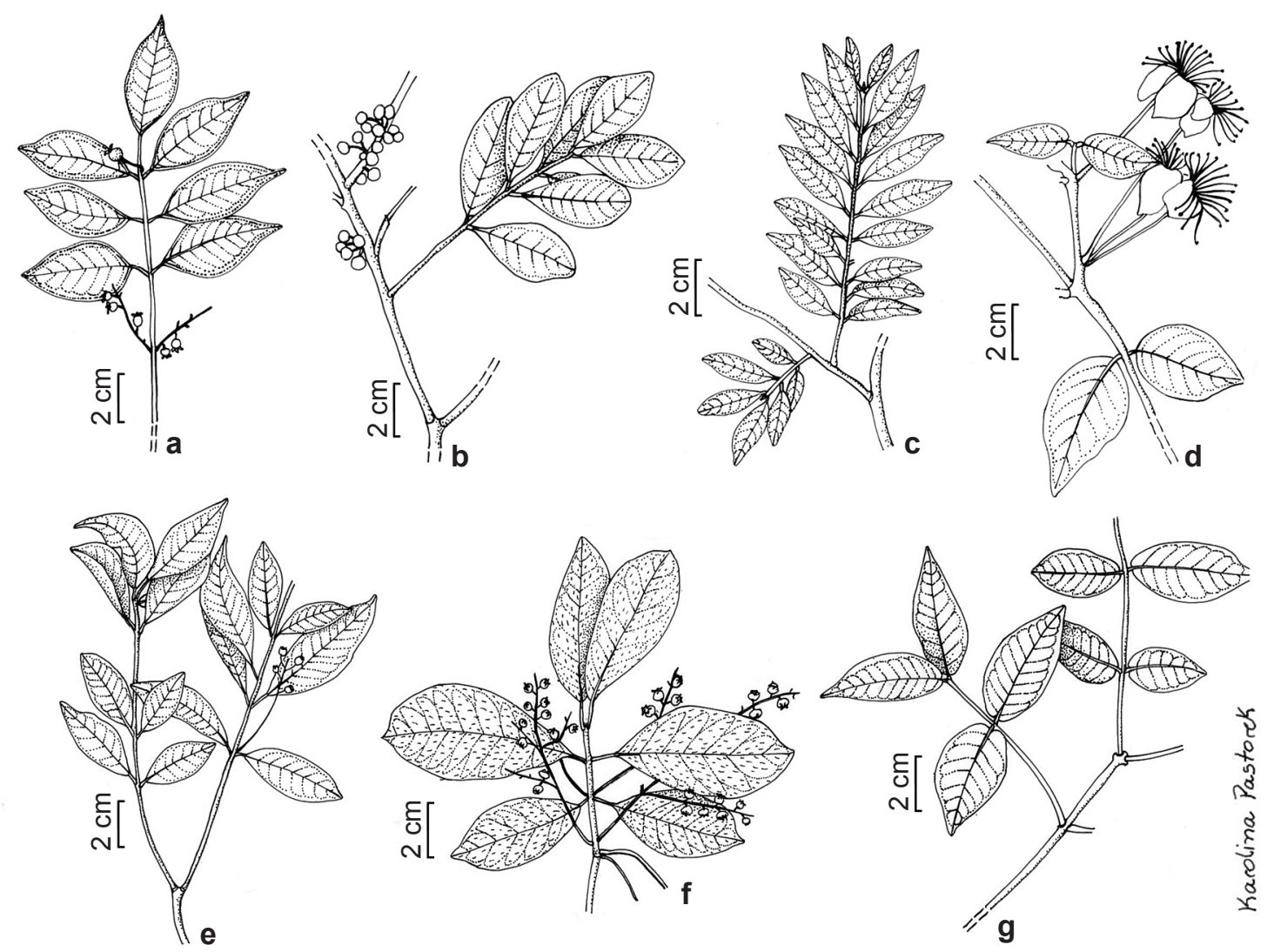

Figura 4 - a. Eugenia paracatuana - ramo frutífero. b. Eugenia pluriflora - ramo com flores em glomérulos. c. Eugenia pyriformis - ramo vegetativo. d. Eugenia uniflora - ramo florífero. e. Myrcia multiflora - ramo com frutos. f. Myrcia tomentosa - ramo com frutos. g. Myrcia uberavensis - ramo com folhas subsésseis e base subcordada (a. A.T. Silva 21; b. A.T. Silva \& L.E.G.D. Nogueira 57; c. A.T. Silva 55; d. A.T. Silva 67; e. A.T. Silva \& L.E.G.D. Nogueira 18; f. A.T. Silva \& F.F. Mazine 24; g. A.T. Silva 58 ).

Figure 4 - a. Eugenia paracatuana - fruiting branch. b. Eugenia pluriflora - branch with flowers in clusters. c. Eugenia pyriformis branch. d. Eugenia uniflora - flowering branch. e. Myrcia multiflora - fruiting branch. f. Myrcia tomentosa - fruiting branch. g. Myrcia uberavensis - branch with subsessile and subcordate leaves. (a. A.T. Silva 21; b. A.T. Silva \& L.E.G.D. Nogueira 57; c. A.T. Silva 55; d. A.T. Silva 67; e. A.T. Silva \& L.E.G.D. Nogueira 18; f. A.T. Silva \& F.F. Mazine 24; g. A.T. Silva 58 ). 
Material examinado: $23^{\circ} 25^{\prime} 51.52$ 'S, $47^{\circ} 37^{\prime} 21.52^{\prime} \mathrm{O}$, 10.X.2012, A.T. Silva 5 (SORO); 2326'31.75"S, 47³5'35.88"'O, 22.XI.2012, A.T. Silva \& L.E.G.D. Nogueira 9 (SORO); 2326'31.87'S, 47³5'35.71'”, 22.XI.2012, A.T. Silva \& L.E.G.D. Nogueira 11 (SORO); $23^{\circ} 26^{\prime} 32.23$ 'S, 47³5'35.47'O, 22.XI.2012, A.T. Silva \& L.E.G.D. Nogueira 15 (SORO); 2325'9.63"S, 47³5'36.19”'O, 19.XII.2012, A.T. Silva 26 (SORO); $23^{\circ} 25^{\prime} 59.85$ "S, 47³5'41.52"O, 10.I.2013, A.T. Silva 29 (SORO); 2325'34.03”S, 47³7'12.04”O, 14.II.2013, A.T. Silva 50 (SORO); 2325'9.66”'S, 47³5'35.93”O, 14.II.2013, A.T. Silva 69 (SORO); Fazenda Ipanema, porteira da Fepasa, 4.XII.1998, fr., A.M.G.A. Tozzi 384 (UEC).

Material adicional examinado: BRASIL, MINAS GERAIS, Monte Belo, fazenda Lagoa, mata da Olaria, 24.VIII.1985, fl., J.Y. Tamashiro et. al 17718 (UEC).

A espécie ocorre desde a América Central até o sul da América tropical (Govaerts et al. 2008). BFG (2015) confirmam a ampla ocorrência da espécie em território nacional. Na FLONA Ipanema a espécie foi encontrada no interior e bordaduras de Floresta Estacional Semidecidual.

Eugenia florida se diferencia das outras Myrtaceae do local de estudo por apresentar: folhas com grande variação em relação ao tamanho, coloração arroxeada quando jovens, com o primeiro par de nervuras secundárias não confluentes com as demais e pela presença de duas nervuras marginais, além das flores reunidas racemos.

Nos herbários é comum encontrar materiais de $E$. florida erroneamente identificados como $E$. paracatuana e vice versa. A principal característica morfológica para diferenciar as duas espécies é a inflorescência em racemos em $E$. florida, e em $E$. paracatuana a inflorescência em cimeira.

\subsection{Eugenia francavilleana O.Berg, Linnaea 30 :} 686. 1861

Fig. 3e

Arvoretas ou árvores de 2-5 m de alt.; ramos jovens castanho-amarelados, glabros ou com esparso indumento prateado, achatado nas partes terminais, sem pontuações translúcidas; ramos adultos variando de acinzentados até castanho-amarelados, glabros. Folhas com pecíolo castanho-amarelado ou verde-amarelado, glabro ou com esparso indumento argênteo, canaliculado ou cilindrico, de 2-10 mm de compr., sem pontuações translúcidas; lâminas de 35-110 × 13-46 mm, elípticas, estreito-elípticas, lanceoladas, obovais ou oblanceoladas; ápice cuspidado, acuminado, atenuado, agudo ou raramente arredondado, base aguda, atenuada ou raramente obtusa; faces adaxial e abaxial glabra ou com esparso e curto indumento argênteo, sem tufos de tricomas entre nervura central e secundária, discolores, subcoriáceas ou coriáceas; margem revoluta ou não revoluta, plana; nervura central levemente sulcada na face adaxial e saliente na face abaxial, de 10-25 pares de nervuras secundárias inconspícuas, nervura marginal paralela à borda ou em arcos, de 0,5-1,0 $\mathrm{mm}$ da margem, raramente duas nervuras marginais, a interna de 1-4 $\mathrm{mm}$ da margem; pontuações translúcidas visíveis a olho nu, saliente em ambas as faces. Flores em fascículo com o eixo na base castanho-avermelhado, axilares, indumento argênteo; pedúnculo com 4-10 mm de compr., castanho-avermelhado, indumento argênteo, sem pontuações translúcidas; sépalas 4, triangulares, $1,5 \mathrm{~mm}$ de base e alt., indumento argênteo; pétalas 4, $3 \times 3 \mathrm{~mm}$. Bagas globosas, não costadas, vermelhas quando maduras, com 10-13 mm de diâm., com indumento argênteo, presença de pontuações translúcidas.

Material examinado: área 1, 12.IX.2008, fr., M.F. Casali 97 (SORO, IAC); 2325'56.32'S, 47³6'34.07'O, 27.IX.2012, A.T. Silva 3 (SORO); 2325'31.79”S, 47³6'6.00”O, 7.III.2013, A.T. Silva 60 (SORO); $23^{\circ} 25^{\prime} 52.79$ 'S, 47³6'22.58”O, 7.III.2013, A.T. Silva 61 (SORO).

Material adicional examinado: BRASIL, SÃO PAULO, Campinas, Bosque dos Jequitibás, 10.X.1978, fl., L.A.F. Mathes 9928 (UEC).

A espécie ocorre na Paraíba e nas regiões Sudeste e Centro-Oeste do Brasil, em fragmentos de Mata Atlântica e Cerrado (BFG 2015).

Esposito-Polesi et al. (2011) citam E. francavilleana como E. glazioviana, com caracteres que indicam adaptação a ambientes xéricos, como: folha hipoestomática, face adaxial e abaxial com cutícula espessa. Na FLONA Ipanema a espécie foi encontrada no interior da Floresta Estacional Semidecidual em ambientes com solos rasos (próximo de afloramentos rochosos) na trilha da Pedra Santa e nos arredores.

3.4. Eugenia ligustrina (Sw.) Willd., Sp. Pl. ed. 4 [Willdenow] 2(2): 962. $1799 . \quad$ Fig. 3f

Arvoretas ou árvores de 1,6-5,5 m de alt.; ramos jovens castanho-amarelados, glabros, podendo ocorrer ritidoma descamante castanhoavermelhado com curto indumento ferrugíneo, cilíndrico nas partes terminais, sem pontuações translúcidas; ramos adultos castanho-amarelados, glabros. Folhas com pecíolo de 2-4 mm de compr., verde-claro, glabro ou com curto indumento ferrugíneo, canaliculado, sem pontuações translúcidas; lâminas de 25-60 × 10-30 mm, ovais, obovais, elípticas ou estreito-elípticas; ápice 
agudo ou atenuado, base atenuada ou aguda; face adaxial e abaxial glabra, discolores, cartáceas; margem revoluta, plana; nervura central sulcada na face adaxial e saliente na face abaxial, mais que 20 pares de nervuras secundárias, nervura marginal em arcos, de 0,5-2,0 $\mathrm{mm}$ da margem; pontuações translúcidas visíveis a olho nu, salientes em ambas as faces. Flores solitárias ou em fascículos, terminais, em nós bracteados; pedúnculo verdeclaro, de 2-30 mm de compr., curto indumento argênteo, sem pontuações translúcidas; bractéolas castanho-avermelhadas reluzentes, retusas $0,5-1,0$ $\times 0,3 \mathrm{~mm}$; sépalas $4,6 \times 1-3 \mathrm{~mm}$, presença de pontuações translúcidas; pétalas $4,8-10 \times 5 \mathrm{~mm}$, sem pontuações translúcidas. Bagas globosas, não costadas, roxas quando maduras, com 5-7 $\mathrm{mm}$ de diâm., presença de pontuações translúcidas.

Material examinado: $23^{\circ} 25^{\prime} 57.93^{\prime \prime} \mathrm{S}, 47^{\circ} 36^{\prime} 39.31^{\prime \prime} \mathrm{O}$, 27.IX.2012, A.T. Silva 2 (SORO); 2325'51.55”'S, 47³7'20.93"O, 10.X.2012, A.T. Silva 4 (SORO); $23^{\circ} 25^{\prime} 47.26^{\prime \prime}$, $47^{\circ} 37^{\prime} 21.40^{\prime \prime}$ O, 10.X.2012, A.T. Silva 6 (SORO); 232 25'46.39"S, 47³7'20.85”O, 10.X.2012, fl., A.T. Silva 7 (SORO).

Material adicional examinado: BRASIL, SÃO PAULO: Bauru, Jardim Botânico Municipal de Bauru, 31.X.1996, fr., M.H. Ongaro Pinheiro 178 (UEC); Jundiaí, Serra do Japí, 15.X.1984, f1., G.L. Webster 25417 (UEC).

A espécie é de ampla distribuição Neotropical, ocorrendo desde o Caribe até o Paraná (Govaerts et al. 2008; BFG 2015).

Na FLONA Ipanema a espécie foi encontrada no interior da Floresta Estacional Semidecidual, próximo ao topo do morro Araçoiaba, trilha Afonso Sardinha, local atravessado por córregos. As principais características de E. ligustrina são suas flores delicadas surgindo no ápice dos ramos mais novos, bractéolas retusas e folhas discolores.

\subsection{Eugenia paracatuana O.Berg, Fl. Bras.} (Martius) 14(1): 588. 1859.

Fig. 4a

Arvoretas ou árvores de 1,8-8,0 m de alt.; ramos jovens variam de castanho-amarelados, castanho-alaranjados até castanho acinzentados, curto indumento castanho-amarelado, ligeiramente achatado nas partes terminais, podendo apresentar pontuações translúcidas; ramos adultos castanhoamarelados, glabros, podem apresentar pontuações translúcidas. Folhas com pecíolos de 5-6 mm de compr., castanho-esverdeados, curto indumento castanho-amarelado, canaliculados, sem pontuações translúcidas; lâminas de 45-70 × 15-40 mm, ovais, raramente obovais ou largo-elípticas; ápice acuminado ou atenuado, base atenuada; face adaxial glabra ou com curto indumento na região da nervura central, e face abaxial glabra ou com esparso e curto indumento castanho-amarelado, concolores, subcoriáceas; margem não revoluta, plana; nervura central sulcada na face adaxial e saliente na face abaxial, de 6-15 pares de nervuras secundárias, duas nervuras marginais, a interna em arcos, de 2-4 mm da margem; poucas pontuações translúcidas visíveis apenas em lupa, saliente em ambas as faces. Flores em cimeiras axilares; pedúnculo castanho-alaranjado, indumento castanho-amarelado ou preto, com 5-6 $\mathrm{mm}$ de compr., sem pontuações translúcidas, pedicelo de 3-4 mm de compr.; sépalas 4, triangulares, 1-2 mm de base e alt., presença de pontuações translúcidas; pétalas 4, 2,5-3,0 × 1,5-2,0 $\mathrm{mm}$, sem pontuações translúcidas. Bagas globosas, não costadas, pretas quando maduras, lustrosas, $5 \mathrm{~mm}$ de diâm., com esparso e curto indumento castanho-amarelado ou preto.

Material examinado: $23^{\circ} 26^{\prime} 31.72^{\prime \prime} \mathrm{S}, 47^{\circ} 35^{\prime} 35.89^{\prime \prime} \mathrm{O}$, 22.XI.2012, fr., A.T. Silva \& L.E.G.D. Nogueira 8 (SORO); 2326'33.13”'S, 47³5'35.08”'O, 22.XI.2012, fr., A.T. Silva \& L.E.G.D. Nogueira 21 (SORO); $23^{\circ} 25^{\prime} 9.98^{\prime \prime}$ 'S, 47³5'36.27'O, 19.XII.2012, fr., A.T. Silva 27 (SORO); $23^{\circ} 25^{\prime} 58.21^{\prime \prime}$ 'S, 47 $7^{\circ} 35^{\prime} 33.90^{\prime \prime}$, 10.I.2013, fr., A.T. Silva 31 (SORO); 2326'34.66”'S, 47³5'24.85"O, 31.I.2013, fr., A.T. Silva 45 (SORO);

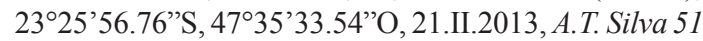
(SORO); 2325'56.70"S, 47³5'33.94"O, 21.II.2013, fr.,

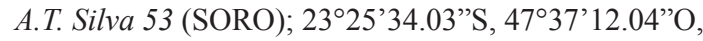
14.III.2013, fr., A.T. Silva 64 (SORO).

Material adicional examinado: BRASIL, PARANÁ, Cataratas do Iguaçu, 1-2 km acima da Garganta do Diabo, 150 m, 18.IX.1976, fl., G.C. Shepherd 60983 (UEC).

Segundo Govaerts et al. (2008), a espécie ocorre desde o sudeste do Brasil até o Paraguai. BFG (2015) ampliam a ocorrência para Mato Grosso, Mato Grosso do Sul e Goiás, nos domínios da Mata Atlântica e Cerrado.

Na FLONA Ipanema a espécie é muito frequente e foi encontrada próximo das clareiras e bordaduras em Floresta Estacional Semidecidual.

\subsection{Eugenia pluriflora DC., Prodr. [A. P. de} Candolle] 3: 270. 1828.

Fig. 4b

Arvoreta de $2 \mathrm{~m}$ de alt.; ramos jovens castanho-amarelados, glabro, ligeiramente achatado nas partes terminais; ramos adultos acinzentados, glabros. Folhas com pecíolos verde-claros, glabros, canaliculados, de $2-5 \mathrm{~mm}$ de compr., sem pontuações translúcidas; lâminas de 40-70 × 20-30 $\mathrm{mm}$, obovais, raramente elípticas; ápice agudo ou arredondado, base aguda; face adaxial e abaxial glabras, discolores, coriáceas; margem revoluta, 
plana; nervura central sulcada na face adaxial e saliente na face abaxial, de 8-12 pares de nervuras secundárias, nervura marginal em arcos, de 2-3 mm da margem; muitas pontuações translúcidas visíveis a olho nu, salientes em ambas as faces. Flores em glomérulos ramifloros; pedúnculo verdeclaro, de 1,5-6,0 mm de compr., glabro, presença de pontuações translúcidas; sépalas 4, 0,5-1,5 $\times 0,5-1,5 \mathrm{~mm}$; pétalas $4,4 \times 3-4 \mathrm{~mm}$. Bagas globosas, não costadas, imaturas, 1,5-3,0 mm de diâm., glabras, com muitas pontuações translúcidas visíveis ao olho nu.

Material examinado: $23^{\circ} 26^{\prime} 1.82^{\prime} \mathrm{S}, 47^{\circ} 36^{\prime} 41.92$ 'O, 28.II.2013, fr., A.T. Silva \& L.E.G.D. Nogueira 57 (SORO).

Material adicional examinado: BRASIL, PARANÁ, Cerro Azul, Estrada para Cerro Azul, fazenda, 1.XI.2003, fr., F.F. Mazine et. al 961 (UEC); SÃO PAULO, Morungaba, Observatório Capricórnio, 29.I.1986, fl., N. Taroda \& K. Yamamoto 18312 (UEC).

A espécie é endêmica do Brasil, ocorrendo desde a Bahia ao Rio Grande do Sul, sempre em áreas de Mata Atlântica (BFG 2015).

Na FLONA Ipanema a espécie foi coletada no alto do morro Araçoiaba, subindo a trilha da Pedra Santa, próximo da primeira cruz, local com afloramentos rochosos.

As principais características de E. pluriflora são suas folhas coriáceas, glabras, discolores, com margem revoluta e inflorescências ramifloras.

\subsection{Eugenia punicifolia (Kunth) DC., Prodr. [A.} P. de Candolle] 3: 267. 1828.

Arbusto de 1,5 m de alt.; ramos jovens castanho-amarelados ou castanho-avermelhados, glabros ou com indumento castanho-amarelado, cilíndrico nas partes terminais, sem pontuações translúcidas; ramos adultos castanho-amarelados ou castanho-avermelhados, ritidoma marromesbranquiçado, glabros. Folhas com pecíolos castanho-amarelados ou castanho-avermelhados, glabros (nas folhas jovens podem apresentar indumento castanho-amarelado), enrugados, levemente canaliculados, de 2-3 $\mathrm{mm}$ de compr., sem pontuações translúcidas; lâminas de 40$70 \times 15-35 \mathrm{~mm}$, estreito-elípticas, elípticas, oblanceoladas ou ovais; ápice agudo-arredondado ou atenuado-arredondado, base aguda ou raramente atenuada; face adaxial e abaxial glabra (face abaxial das folhas jovens pode apresentar indumento castanho-amarelado), discolores com face adaxial lustrosa, coriáceas; margem revoluta ou não revoluta, plana; nervura central sulcada na face adaxial e saliente na face abaxial, de 10-20 pares de nervuras secundárias, nervura marginal paralela à borda, de 0,5-2,0 mm da margem; pontuações translúcidas visíveis apenas em lupa, salientes em ambas as faces. Flores solitárias ou em fascículos, axilares, em nós desprovidos de brácteas; pedúnculo castanho-claro a castanho-escuro com 10-20 mm de compr., glabro, poucas pontuações translúcidas; sépalas $4,3 \times 3 \mathrm{~mm}$, margem ciliada, pétalas 4 , $6 \times 4 \mathrm{~mm}$, glabra, margem ciliada; hipanto com pontuações translúcidas; bractéolas pubescentes. Bagas globosas alongadas, não costadas, vermelho amarelada quando madura, $12-14 \mathrm{~mm}$ de compr. e 5-10 mm de larg., glabras, com pontuações translúcidas.

Material examinado: Fazenda Ipanema, 6.VIII.1994, fl., R.R. Rodrigues et al. 74 (ESA, UEC).

Material adicional examinado: BRASIL, SÃO PAULO, Sorocaba, Avenida Independência, Éden, 20.X.2001, fr., A.C.R. Gonçalves (SORO 1418).

Segundo Govaerts et al. (2008), a espécie ocorre desde Cuba até o sul da América do Sul. BFG (2015) citam que ocorre em todos os domínios vegetacionais nacionais, exceto nos campos sulinos.

Apesar de as folhas de E. punicifolia apresentar muita variação de tamanho e forma, a espécie pode ser identificada pela textura muito coriácea e ausência de indumento nas folhas (raramente presente nas folhas jovens).

3.8. Eugenia pyriformis Cambess., Fl. Bras. Merid. (A. St.-Hil.). ii. 336. 1833.

Fig. 4c

Árvore de $5 \mathrm{~m}$ de alt.; ramos jovens castanhoavermelhados, indumento castanho-amarelado ou bronzeado, cilíndrico nas partes terminais, sem pontuações translúcidas; ramos adultos castanhoacinzentados e/ou castanho-avermelhados, tricomas isolados castanho-amarelados. Folhas com pecíolos de 2-4 mm de compr., verde-claros, com o mesmo tipo de indumento dos ramos novos, sem pontuações translúcidas; lâminas de 12-40 $\times$ 5-12 mm, lanceoladas ou estreito-elípticas; ápice e base agudos; face adaxial e abaxial com esparso e curto indumento castanho-amarelado mais concentrado ao longo da nervura central, ligeiramente discolores, subcoriáceas; margem não revoluta, plana; nervura central saliente em ambas as faces, de 15-25 pares de nervuras secundárias, nervura marginal em arcos, de 0,5-1,5 $\mathrm{mm}$ da margem; pontuações translúcidas visíveis apenas em lupa, saliente em ambas as faces. Flores em dicásio, axilares, surgindo junto com os ramos 
novos; pedúnculo com 3-10 mm de compr. varia de castanho-amarronzado até castanho-amarelado, indumento argênteo, sem pontuações translúcidas; botão floral em antese com sépalas divididas em 4 lobos arredondados, individualizados, $1 \mathrm{~mm}$ de diâm.; bractéolas de $1 \mathrm{~mm}$ de compr., indumento argênteo. Bagas piriformes, não costadas, amarelas quando madura, $15 \times 10 \mathrm{~mm}$, com pontuações translúcidas e indumento argênteo.

Material examinado: Fazenda Ipanema, VIII.1998, fl., M.G. Silva (SP 329.660); 2325’33.74”'S, 47035'56.84”O, 21.II.2013, A.T. Silva 55 (SORO).

Material adicional examinado: BRASIL, SÃO PAULO, Mogi Guaçu, fazenda Campininha, 20.X.1978, fr., H.F. Leitão Filho et. al 9132 (UEC).

A espécie ocorre desde o Brasil até Paraguai, Uruguai e nordeste da Argentina, presente em áreas de Mata Atlântica e Cerrado (Govaerts et al. 2008; BFG 2015).

Na FLONA Ipanema a espécie foi encontrada em um quintal de uma casa abandonada, possivelmente cultivada, porém, segundo informações locais, também existem exemplares que ocorrem espontaneamente nas matas.

As flores reunidas em dicásios e frutos piriformes são as principais características de $E$. pyriformis. Além disso, suas folhas apresentam tamanho reduzido, quando comparado com as outras espécies de Myrtaceae da área em estudo, com indumento castanho-amarelado concentrado na nervura central e lâminas estreito-elípticas a lanceoladas.

\subsection{Eugenia uniflora L., Sp. Pl. 1: 470. 1753.}

Fig. $4 d$

Arvoretas ou árvores de 1,5-5,0 m de alt.; ramos jovens castanho-acinzentados e/ou castanhoamarelados, glabros ou com indumento castanhoamarelado, cilíndrico nas partes terminais, sem pontuações translúcidas; ramos adultos de mesma cor dos ramos jovens, glabros ou com tufos isolados de tricomas pretos. Folhas com pecíolo verde-claro, glabro ou com indumento castanho-amarelado, canaliculado ou cilíndrico, de 1-3 mm de compr., sem pontuações translúcidas; lâminas de 20-60 × 15-40, ovais, largo-elípticas ou elípticas; ápice atenuado, agudo ou obtuso, base arredondada, aguda ou obtusa; face adaxial e abaxial glabra, discolores, cartáceas ou subcoriáceas; margem revoluta ou não, plana; nervura central sulcada ou saliente na face adaxial e saliente na face abaxial, de 4-10(-18) pares de nervuras secundárias, nervura marginal em arcos, de 0,5-3,0 $\mathrm{mm}$ da margem; pontuações translúcidas visíveis apenas em lupa, saliente em ambas as faces. Flores solitárias ou em fascículos, axilares; pedicelo verdeclaro, com 20-30 mm de compr., glabro, presença de pontuações translúcidas; sépalas 4, 2-3× 1,0-1,5 $\mathrm{mm}$, glabras, presença de pontuações translúcidas; pétalas 4, 5×2-5 mm, indumento argênteo, ausência de pontuações translúcidas. Bagas globoso-costadas; vermelho-alaranjadas quando maduras, $10-15 \mathrm{~mm}$ de diâm., com pontuações translúcidas.

Material examinado: $23^{\circ} 25^{\prime} 29.24^{\prime \prime} \mathrm{S}, 4^{\circ} 35^{\prime} 52.68^{\prime \prime} \mathrm{O}$, 10.I.2013, fl. e fr., A.T. Silva 30 (SORO); $23^{\circ} 26^{\prime} 00.9^{\prime \prime}$ 'S, 47 36'31.4" O, 24.I.2013, A.T. Silva 38 (SORO);

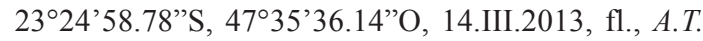
Silva 67 (SORO).

Material adicional examinado: BRASIL, SÃO PAULO, Campinas, Bosque dos Alemães, 11.X.1990, fr., V. Stranghetti et. al 23.574 (UEC).

A espécie ocorre desde a Bahia até o Paraguai, Uruguai e Argentina (Govaerts et al. 2008; BFG 2015), em áreas de Cerrado, Mata Atlântica e Campos sulinos.

Na FLONA Ipanema a espécie foi encontrada no interior da Floresta Estacional Semidecidual e na orla da floresta, próxima a represa Hedberg. Indivíduos cultivados estão presentes nas cercanias das edificações e vilas.

Os frutos de E. uniflora são caracteristicamente costados longitudinalmente. $\mathrm{O}$ tronco é acinzentado e/ou esbranquiçado podendo haver regiões esverdeadas em locais onde a casca se desprendeu. As folhas normalmente apresentam poucas nervuras secundárias.

\subsection{Eugenia sp.}

Árvore de $4 \mathrm{~m}$ de alt.; ramos jovens castanhoamarelados até amarelo-palha, glabros, cilíndrico nas partes terminais, presença de pontuações translúcidas; ramos adultos de mesma cor dos ramos jovens, tricomas curtos, pretos, isolados ou em tufos. Folhas com pecíolos verde-amarelados, glabros, canaliculados, de 3-4 mm de compr., presença de pontuações translúcidas; lâminas de 25-40 × 10-20 mm, ovais ou estreito-elípticas; ápice atenuado, base aguda ou atenuada; face adaxial e abaxial glabra, porém, na face abaxial pode existir tricomas isolados e muito esparsos de cor verde-amarelo, discolores, subcoriáceas; margem revoluta, plana; nervura central levemente sulcada na face adaxial e saliente na face abaxial, de 12-18 pares de nervuras secundárias, nervura marginal em arcos, de 1-3 $\mathrm{mm}$ da margem; pontuações translúcidas visíveis a olho nu, saliente em ambas as faces. Flores e frutos não vistos. 
Material examinado: $23^{\circ} 25^{\prime} 58.60^{\prime} \mathrm{S}, 47^{\circ} 36$ '26.96”O, 7.III.2013, A.T. Silva 62 (SORO).

$\mathrm{Na}$ FLONA Ipanema, foi encontrada em bordadura de Floresta Estacional Semidecidual, próximo à trilha da Pedra Santa.

Eugenia sp. apresenta certa semelhança com E. pyriformis, porém em Eugenia sp. as folhas raramente apresentam indumento e são ovaladas. A ausência de coleta de exemplares com estruturas reprodutivas impossibilitou a identificação específica.

4. Myrcia DC., Dict. Class. Hist. Nat. [Bory] 11: 406 (378, 401). 1827.

Fig. 4e,f,g

Arbustos a árvores, sem ramificação dicotômica. Bractéolas decíduas ou persistentes na antese. Flores pentâmeras, reunidas em panículas axilares ou terminais; pétalas presentes; cálice com lobos abertos e livres no botão, na antese os botões abrem-se de maneira regular ou irregular; ovário com 2-3 lóculos; 2 óvulos por lóculo; placentação axilar. Bagas coroadas pelos lobos do cálice ou remanescentes; 1-2 sementes por fruto; testa membranácea a crustosa; embrião tipo mircioide.

Segundo Landrum \& Kawasaki (1997) e Govaerts et al. (2008) o gênero ocorre desde o México até o norte da Argentina, e são estimadas 395 espécies. No Brasil, ocorrem 260 espécies sendo 207 endêmicas. Estão presentes em todos os estados e domínios vegetacionais brasileiros, principalmente Mata Atlântica, Cerrado e Amazônia (BFG 2015). Na FLONA Ipanema ocorrem quatro espécies.

4.1. Myrcia multiflora (Lam.) DC., Prodr. [A. P. de Candolle] 3: 244. $1828 . \quad$ Fig. 4e

Arvoreta ou árvore de 1,2-5,0 m de alt.; ramos jovens castanho-amarelados, indumento argênteo não sensível ao tato, cilíndrico ou levemente achatado nas partes terminais, presença de pontuações translúcidas; ramos adultos apresentam a mesma cor dos ramos jovens, ritidoma descamante esbranquiçado, glabros. Folhas com pecíolos de 2-7 mm de compr., esverdeados, subglabros ou com curto indumento argênteo nas folhas jovens, canaliculados, sem pontuações translúcidas; lâminas de 30-80 × 10-35 mm, elípticas, estreitoelípticas, ovais ou obovais; ápice agudo ou atenuado, base atenuada ou cuneada; face adaxial e abaxial glabra ou com tricomas isolados e argênteos às vezes mais densos na nervura central, discolores, cartáceas ou subcoriáceas; margem revoluta ou não revoluta, plana; nervura central de cor amarela, levemente sulcada na face adaxial e saliente na face abaxial, mais de 15 pares de nervuras secundárias, nervura marginal em arcos, de 0,2-2,0 $\mathrm{mm}$ da margem; muitas pontuações translúcidas visíveis a olho nu, saliente em ambas as faces. Flores em panículas axilares; pedúnculo esverdeado, de 25-45 mm de compr., glabro, presença de pontuações translúcidas; sépalas 5, 1,5-2,0 × 1,0-1,5 mm, sem pontuações translúcidas; pétalas $5,1 \times 1$ $\mathrm{mm}$, presença de pontuações translúcidas. Bagas globosas, não costadas, roxas quando maduras, 5 mm de diâm., glabras, com pontuações translúcidas. Material examinado: $23^{\circ} 26^{\prime} 32.42^{\prime} \mathrm{S}, 47^{\circ} 35^{\prime} 35.45^{\prime} \mathrm{O}$, 22.XI.2012, A.T. Silva \& L.E.G.D. Nogueira 13 (SORO); 2326'32.71"S, 47³5'35.12"O, 22.XI.2012, fr., A.T. Silva \& L.E.G.D. Nogueira 18 (SORO); 2326'00.9"' S, 47³6’31.4” O, 24.I.2013, A.T. Silva 40 (SORO).

Material adicional examinado: BRASIL, RIO GRANDE DO SUL, Guaíba, 15.XII.1989, fl., J. Larocca 2598 (UEC).

Segundo Govaerts et al. (2008), a espécie ocorre desde a América Central até sul da América Tropical. BFG (2015), confirmam a ampla ocorrência em todo território nacional, presente em todos os domínios vegetacionais, exceto nos campos sulinos.

Na FLONA Ipanema a espécie foi encontrada no interior da Floresta Estacional Semidecidual, no sopé do morro Araçoiaba, fragmento próximo ao cemitério protestante.

M. multiflora pode ser diferenciada de outras espécies de Myrtaceae no local de estudo por apresentar: tronco esbranquiçado com manchas marrons ou castanhas, ritidoma descamante, indumento escasso, folhas com nervura reticulada.

4.2. Myrcia tomentosa (Aubl.) DC., Prodr. [A. P. de Candolle] 3: 245. $1828 . \quad$ Fig. $4 f$

Arvoretas ou árvores de 1-5 $\mathrm{m}$ de alt.; ramos jovens castanho-amarelados, denso indumento amarelo-palha sensível ao tato, cilíndrico nas partes terminais, sem pontuações translúcidas; ramos adultos castanho-amarelados até castanhoavermelhados, glabros. Folhas com pecíolos de mesma cor e indumento dos ramos novos, canaliculados, 5-15 mm de compr., sem pontuações translúcidas; lâminas de 35-90 × 20-45 mm, elípticas, obovais ou oblanceoladas; ápice agudo, atenuado, cuspidado, arredondado ou obtuso, base aguda ou atenuada; face adaxial e abaxial com denso indumento amarelo-palha sensível ao tato, discolores, subcoriáceas ou coriáceas; margem não revoluta, plana; nervura central sulcada 
na face adaxial e saliente na face abaxial, de 7-16 pares de nervuras secundárias, nervura marginal em arcos, de 1-5 $\mathrm{mm}$ da margem; pontuações translúcidas visíveis apenas em lupa, saliente em ambas as faces. Flores em panículas concentradas no ápice do ramo; pedúnculo castanho-amarelado até castanho-amarronzado, de 5-20 $\mathrm{mm}$ de compr., denso indumento amarelo-palha ou subglabro, sem pontuações translúcidas; sépalas 5 , triangulares, $2 \mathrm{~mm}$ de base e $1 \mathrm{~mm}$ de altura, castanho-amareladas; pétalas $5,1-2 \times 1-2 \mathrm{~mm}$. Bagas concentradas no ápice dos ramos; globosas, não costadas, pretas quando maduras, de $4-5 \mathrm{~mm}$ de diâm., com denso indumento amarelo-palha, presença de pontuações translúcidas.

Material examinado: Fazenda Ipanema, 6.VIII.1994, fl., J.Y. Tamashiro et al. 450 (SPSF, SP); 2326'34.86”'S, 47³5'24.15"O, 22.XI.2012, A.T. Silva \& L.E.G.D. Nogueira 23 (SORO); 2325'59.99”'S, 47³7'19.03”O, 28.XI.2012, fr., A.T. Silva \& F.F. Mazine 24 (SORO); $23^{\circ} 26^{\prime} 25.89^{\prime \prime}$, $47^{\circ} 35^{\prime} 52.54^{\prime \prime}$, 7.II.2013, fl., A.T.

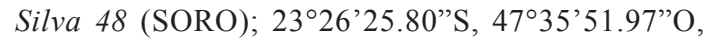
7.II.2013, fr., A.T. Silva 49 (SORO); 2325'11.27'S, 47³5’37.46”O, 14.III.2013, A.T. Silva 70 (SORO).

Material adicional examinado: BRASIL, DISTRITO FEDERAL, Bacia do Rio São Bartolomeu, próximo ao Córrego Rajadinha, 13.X.1993, fl., R.C. Mendonça 281 (UEC).

A espécie é amplamente distribuída ocorrendo desde a América Central até sul da América do Sul (Govaerts et al. 2008). BFG (2015), confirmam a ampla ocorrência em todo território nacional, presente em todos os domínios vegetacionais, exceto nos campos sulinos.

$\mathrm{Na}$ FLONA Ipanema a espécie foi encontrada no topo e sopé do morro Araçoiaba em área de Floresta Estacional Semidecidual.

Myrcia tomentosa é uma espécie extremamente variável no que diz respeito as suas folhas. De forma geral, suas características marcantes são o tronco tortuoso, liso e castanhoavermelhado; ramos novos, folhas e frutos com indumento denso (amarelo-palha), e panículas com flores e frutos normalmente mais concentrados no ápice dos ramos.

\subsection{Myrcia uberavensis O.Berg, Fl. Bras. (Martius) 14(1): 568. 1859. Fig. $4 \mathrm{~g}$}

Arvoretas ou árvores de 1,5-5,0 m de alt.; ramos jovens verde-claros ou acinzentados, com denso e longo indumento argênteo, levemente achatado nas partes terminais, presença de pontuações translúcidas; ramos adultos castanho- esverdeados até castanho-avermelhados, glabros. Folhas subsésseis, com pecíolos de $2-3 \mathrm{~mm}$ de compr., verde-claros, indumento argênteo, canaliculados, sem pontuações translúcidas; lâminas de 30-90 × 20-30 mm, ovais ou raramente elípticas; ápice agudo ou atenuado, base subcordada; face adaxial glabra, e face abaxial com indumento argênteo, discolores, subcoriáceas; margem não revoluta, levemente ondulada; nervura central levemente sulcada na face adaxial e saliente na face abaxial, de 10-20 pares de nervuras secundárias, nervura marginal em arcos, de 1-4 mm da margem; pontuações translúcidas visíveis apenas em lupa, saliente em ambas as faces. Flores em panículas; pedúnculo castanho, de 10-30 mm de compr., ligeiramente achatado nas pontas, indumento castanhoamarelado, sem pontuações translúcidas; pedicelos de 1,5-2,0 $\mathrm{mm}$ de compr., com indumento castanho-amarelado; sépalas 5, 1,5$2,0 \times 1,5 \mathrm{~mm}$, indumento castanho-amarelado e pontuações translúcidas; pétalas $5,5 \times 4 \mathrm{~mm}$, às vezes com indumento castanho-amarelado, sem pontuações translúcidas. Bagas elipsoides, não costadas, $6-8 \times 3-5 \mathrm{~mm}$, vináceas quando maduras, com indumento castanho-amarelado e pontuações translúcidas.

Material examinado: $23^{\circ} 26^{\prime} 00.9^{\prime \prime} \mathrm{S}, 4^{\circ} 36^{\prime} 31.4^{\prime \prime}$ O, 24.I.2013, A.T. Silva 37 (SORO); 2326'1.32”S, $47^{\circ} 35^{\prime} 40.65^{\prime}$ "O, 21.II.2013, A.T. Silva 54 (SORO); $23^{\circ} 26^{\prime} 1.82^{\prime \prime}$ 'S, 47³6'41.92"O, 28.II.2013, A.T. Silva \& L.E.G.D. Nogueira 58 (SORO); 2326'3.94"'S, 47³6’29.42”O, 7.III.2013, A.T. Silva 63 (SORO).

Material adicional examinado: BRASIL, GOIÁS, estrada para Piranhas, 23.VI.1966, fl., H.S. Irwin et. al 17.629 (UEC); SÃO PAULO, Casa Branca, 7.XI.1994, fr., L.S. Kinoshita \& J.C. Galvão 94 (UEC).

Segundo Govaerts et al. (2008) e BFG (2015), a espécie é endêmica do Brasil, ocorre em áreas de Cerrado do centro-oeste, além de Minas Gerais e São Paulo.

$\mathrm{Na}$ FLONA Ipanema a espécie foi encontrada em fragmentos da Floresta Estacional Semidecidual e em áreas de transição de Mata Atlântica e Cerrado.

Os espécimes coletados de M. uberavensis possuíam apenas remanescentes florais. A identificação foi validada devido a presença de alguns caracteres típicos, como: folhas subsésseis, base subcordada e nervuras reticuladas. Pode ser diferenciada de M. variabilis por possuir folhas discolores (vs. concolores) e pedúnculos com indumento (vs. glabro). 
4.4. Myrcia variabilis DC., Prodr. [A. P. de Candolle] 3: 254. 1828.

Arbusto de 1,5 m de alt.; ramos jovens castanho-amarronzados, ritidoma descamante acinzentado, glabros ou com indumento castanhoamarelado no ápice, cilíndrico nas partes terminais, sem pontuações translúcidas; ramos adultos castanho-amarronzados, glabros. Folhas com pecíolos castanho-amarelados, glabros ou com indumento castanho-amarelado, canaliculados, de 2,0-3,3 mm de compr., sem pontuações translúcidas; lâminas de 40-65 × 20-30 mm de larg., ovais ou obovais (no ápice dos ramos); ápice agudo ou acuminado, base subcordada; face adaxial glabra ou com esparso e curto indumento castanho-amarelado, face abaxial com esparso indumento castanhoamarelado, concolores, subcoriáceas; margem não revoluta, plana; nervura central saliente em ambas as faces, de 15-20 pares de nervuras secundárias, nervura marginal em arcos, de 1-2 mm da margem; pontuações translúcidas visíveis apenas em lupa, saliente em ambas as faces. Flores em panículas axilares; pedúnculos castanho-amarelados, de 8-30 $\mathrm{mm}$ de compr., glabro, achatados, com pontuações translúcidas; pedicelos de 10-20 mm de compr., glabros, achatados, com pontuações translúcidas; bractéolas com 1,0 mm de compr. e 0,1 mm de larg., ciliadas; botão floral aberto com sépalas divididas em 5 lobos fundidos na base, ciliadas; sépalas $5,1 \times$ $1 \mathrm{~mm}$, indumento castanho-amarelado e pontuações translúcidas; pétalas $5,4 \times 3 \mathrm{~mm}$, glabras, com pontuações translúcidas. Bagas globosas, não costadas, 4 mm de diâm., glabras, com pontuações translúcidas.

Material examinado: Fazenda Ipanema, 6.VIII.1994, fl., R.R. Rodrigues et al. 81 (ESA).

Material adicional examinado: BRASIL, GOIÁS, cerca de $5 \mathrm{~km}$ de Campo Alegre de Goiás, 8.IX.1998, fr., V.C. Souza et. al 21.300 (UEC); MINAS GERAIS: estrada Lagoa Santa-Conceição do Mato de Dentro, 25.IX.2002, fl., K. Yamamoto et. al 133 (UEC); Santana do Riacho, Alto do Curral Queimado, 23.XI.2000, fr., K. Yamamoto \& K. Matsumoto 57 (UEC).

A espécie é endêmica do Brasil, presente em Mata Atlântica e Cerrado, região centro-oeste, além de São Paulo, Minas Gerais e Bahia (BFG 2015).

Na FLONA Ipanema foi coletada em Floresta Estacional Semidecidual, na borda de transição para Cerrado.

Conhecida na área por uma única coleta, $M$. variabilis apresenta folhas variando em formato: no ápice dos ramos são pecioladas e ligeiramente obovais e na base são subsésseis e ovais com base subcordada.
5. Plinia cauliflora (Mart.) Kausel, Ark. Bot. ser. 2, 3: 508. 1956.

Fig. 5a,b

Árvores de $4 \mathrm{~m}$ de alt.; sem ramificação dicotômica; ramos jovens verde-amarelos, indumento argênteo até castanho-amarelado, cilíndrico ou ligeiramente achatado nas partes terminais, sem pontuações translúcidas; ritidoma pardo-amarronzado com manchas mais claras, liso; ramos adultos castanho-amarelados até castanho-avermelhados, glabros. Folhas com pecíolos de 1-2 mm de compr., verdes, com denso indumento castanho-amarelado, sem pontuações translúcidas; lâminas de 17-45 × 9-25 mm, ovais, elípticas, elíptico-lanceoladas ou obovais; ápice cuspidado ou agudo, base arredondada ou raramente cuneada; face adaxial com denso indumento castanho-amarelado na região nervura central, e face abaxial com tricomas esparsos castanho-amarelado na região da nervura central, discolores, subcoriáceas; margem ligeiramente revoluta ou não revoluta, plana, ciliada; nervura central levemente sulcada na face adaxial e saliente na face abaxial, de 14-20 pares de nervuras secundárias, duas nervuras marginais paralelas à borda, a interna a $3 \mathrm{~mm}$ da margem, a externa de 0,5-1,0 $\mathrm{mm}$ da margem; pontuações translúcidas visíveis a olho nu, salientes em ambas as faces. Flores em glomérulos caulifloros com 3-4 flores; pedúnculos esbranquiçados, $4 \mathrm{~mm}$ de compr., com longo e denso indumento argênteo, sem pontuações translúcidas; sépalas $4,1 \times 1 \mathrm{~mm}$, glabras, sem pontuações translúcidas; pétalas $4,2,0 \times 1,5 \mathrm{~mm}$, glabras, sem pontuações translúcidas; ovário com 2 lóculos, 2 óvulos por lóculo. Bagas globosas, não costadas, imaturas, $6 \mathrm{~mm}$ de diâm., com esparso e curto indumento argênteo; 1-2 sementes por fruto; testa membranácea, sementes com embrião eugenioide com cotilédones separados entre si, com hipocótilo reduzido.

Material examinado: $23^{\circ} 24^{\prime} 58.33^{\prime \prime} \mathrm{S}, 47^{\circ} 35^{\prime} 40.17^{\prime \prime} \mathrm{O}$, 10.I.2013, A.T. Silva 34 (SORO); 2324'59.29”'S, $47^{\circ} 35^{\prime} 41.91$ ”'O, 14.III.2013, fl. e fr., A.T. Silva 65 (SORO).

Segundo Govaerts et al. (2008), a espécie ocorre desde a Bolívia até o sul do Brasil. BFG (2015), por sua vez, registram a espécie como endêmica do Brasil com ocorrências no Paraná e em toda a região sudeste, sempre em fragmentos de Mata Atlântica.

Na FLONA Ipanema a espécie foi encontrada em fragmento da Floresta Estacional Semidecidual e ao redor de uma vila abandonada, possivelmente em cultivo, próxima aos assentamentos rurais. 
As principais características de $P$. cauliflora são: tronco liso com muitas ramificações, folhas com duas nervuras marginais paralelas a borda e flores em glomérulos caulifloros.

6. Psidium L., Sp. Pl. 1: 470. 1753 . Figs. 5c,d,e

Arbustos a árvores, sem ramificação dicotômica. Bractéolas decíduas ou persistentes na antese. Flores axilares; solitárias; pétalas presentes; 4-5 meras; cálice fechado ou levemente aberto com 4-5 lobos individualizados no botão; estigma capitulado, ovário com 3-5 lóculos, muitos óvulos por lóculo, placentação parietal intrusiva. Bagas polispérmicas, testa óssea, lustrosa, com opérculo; embrião mirtoide com hipocótilo em forma de " $\mathrm{C}$ ", cotilédones reduzidos.

O gênero, com 95 espécies, distribui-se desde o México até Uruguai e norte da Argentina e ilhas Galápagos (Landrum \& Kawasaki 1997;
Govaerts et al. 2008). No Brasil são registradas 61 espécies, 45 endêmicas, as quais ocorrem em todo território nacional e nos domínios vegetacionais (BFG 2015). Na FLONA Ipanema ocorrem três espécies nativas; Psidium guajava foi encontrada na área de estudo, sendo possivelmente invasora.

6.1. Psidium cattleianum Afzel. ex Sabine, Trans. Hort. Soc. London iv. 317, t. 11. 1821.

Fig. 5c

Arvoretas de 1,6-3,0 m de alt.; ramos jovens e adultos castanho-amarronzados, castanhoamarelados ou castanho-esbranquiçados, glabros, cilíndricos nas partes terminais, presença de pontuações translúcidas. Folhas com pecíolo castanho-amarronzado, glabro, liso, canaliculado, de 5-7 mm de compr., sem pontuações translúcidas; lâminas de 40-80 × 30-50 mm, obovais; ápice

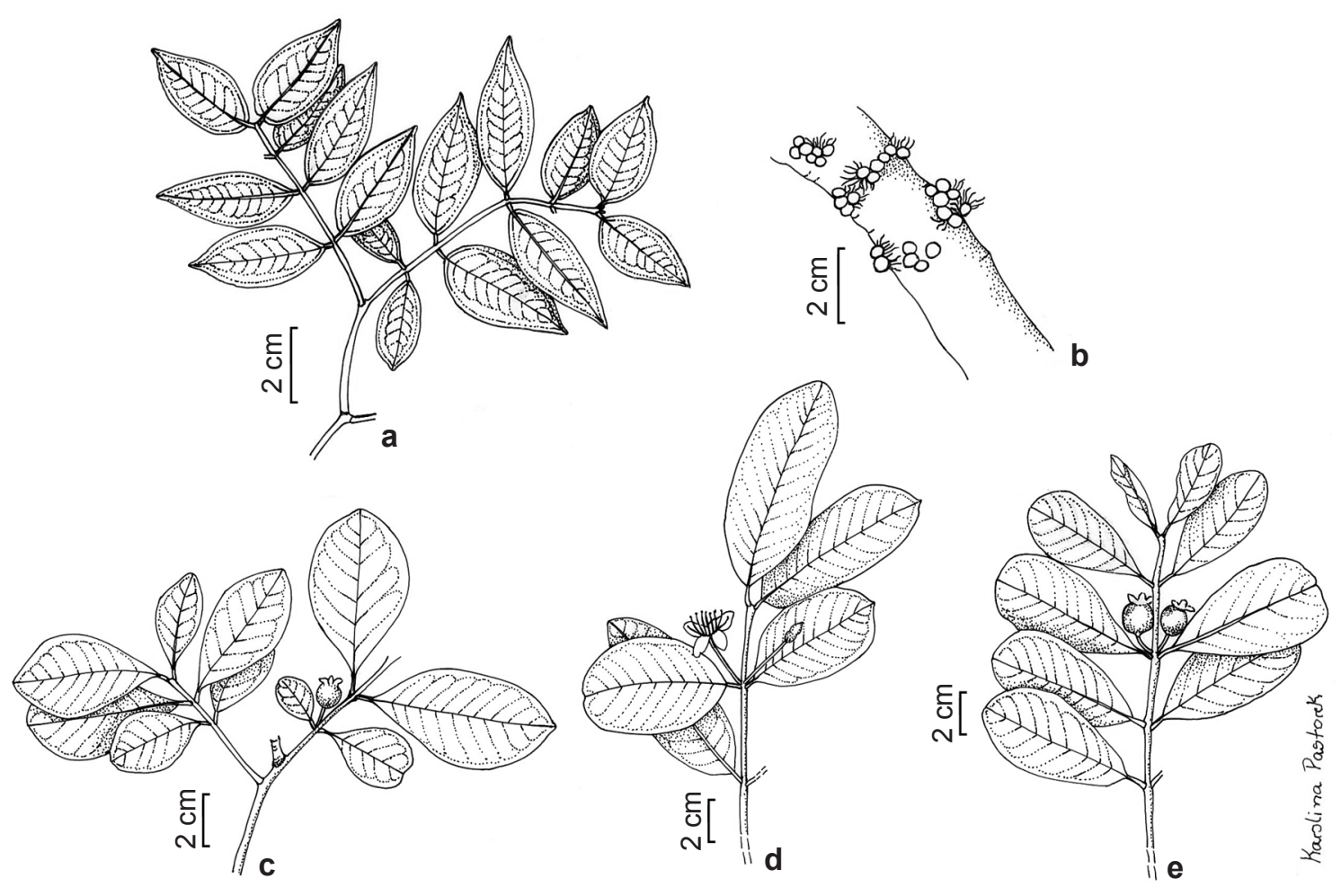

Figura 5 - a. Plinia cauliflora - folhas com duas nervuras marginais paralelas a borda. b. Plinia cauliflora - flores em glomérulos caulifloros. c. Psidium cattleianum - ramo frutífero com folhas predominantemente obovais. d. Psidium guajava - ramo com folhas com 10 a 20 pares de nervuras secundárias. e. Psidium guineense - ramo com folhas com 7 a 9 pares de nervuras secundárias (a. A.T. Silva 65; f. A.T. Silva 65; c. A.T. Silva 33; d. M.F. Casali \& E.A. Costa Jr 143; e. A.T. Silva 36).

Figure 5 - a. Plinia cauliflora - leaves with two marginal veins parallel to the margin. b. Plinia cauliflora-flowers in clusters. c. Psidium cattleianum - fruiting branch with mainly obovate leaves. d. Psidium guajava - branch with leaves with 10 to 20 pairs of secondary veins. e. Psidium guineense - branch with leaves with 7 to 9 pairs of secondary veins (a. A.T. Silva 65; f. A.T. Silva 65; c. A.T. Silva 33; d. M.F. Casali \& E.A. Costa Jr 143; e. A.T. Silva 36). 
cuspidado, arredondado, obtuso ou emarginado, base atenuada ou aguda; faces adaxial e abaxial glabra, discolores, coriáceas; margem revoluta, plana; nervura central sulcada na face adaxial e saliente na face abaxial, de 15-20 pares de nervuras secundárias, nervura marginal em arcos, de 0,5-3,0 mm da margem; pontuações translúcidas visíveis somente em lupa, saliente em ambas as faces. Flores solitárias, axilares; pedúnculo castanho-amarronzado, de 5-8 $\mathrm{mm}$ de compr., indumento muito curto, castanhoamarelado, sem pontuações translúcidas; cálice aberto no botão com 5 lobos individualizados, sépalas 4-5, triangulares, 4-5 × 4-5 mm, presença de pontuações translúcidas; pétalas 4-5, 7-10 × 4 $\mathrm{mm}$, sem pontuações translúcidas. Bagas globosas, não costadas, imaturas, 10 mm de diâm., glabras; sépalas persistentes.

Material examinado: $23^{\circ} 25^{\prime} 49.60^{\prime} \mathrm{S}, 47^{\circ} 35^{\prime} 51.06^{\prime} \mathrm{O}$, 10.I.2013, fr., A.T. Silva 33 (SORO); 2326'23.86"S, 47³5'36.00”O, 31.I.2013, A.T. Silva 43 (SORO); $23^{\circ} 24^{\prime} 59.29$ 'S, 47³5'41.91'O, 14.III.2013, A.T. Silva 66 (SORO).

Material adicional examinado: BRASIL, SÃO PAULO, Cananéia, fazenda Folha Larga, trilha Kaápozanga e trilha Paranã, 20.XI.2003, fl., C. Urbanetz 223 (UEC).

Segundo Govaerts et al. (2008), a espécie ocorre desde o sudeste do Brasil até o nordeste do Uruguai. BFG (2015) referem que a espécie é endêmica do Brasil e incluem registros de ocorrência para Pernambuco, Ceará, Bahia e Sergipe, em áreas de Mata Atlântica, Cerrado e Caatinga.

Na FLONA Ipanema a espécie foi coletada em área de várzea na Floresta Estacional Semidecidual, próximo à represa Hedberg. Também foram encontrados exemplares, estes possivelmente cultivados, próximo dos assentamentos rurais ao redor de uma vila abandonada e em área de reflorestamento.

As principais características de $P$. cattleianum são: folhas coriáceas, predominantemente obovais, glabras, lustrosas e nervuras laterais levemente sulcadas na face abaxial.

\subsection{Psidium guajava L., Sp. Pl. 1: 470. 1753.}

Fig. 5d

Arvoretas ou árvores de 1-8 m de alt.; ramos jovens castanho-amarronzados, indumento argênteo, quadrangulares ou retangulares, sem pontuações translúcidas; ramos adultos castanhoamarronzados, glabros. Folhas com pecíolo castanho-amarelado, indumento castanhoamarelado, de 5-6 mm de compr., sem pontuações translúcidas; lâminas de 60-130 × 35-80 mm, oblongas ou elípticas; ápice arredondado, cuspidado, cuneado ou raramente emarginado, base arredondada ou obtusa; faces adaxial e abaxial com indumento castanho-amarelado, porém, de forma muito esparsa na face adaxial, discolores, coriáceas; margem ligeiramente revoluta, plana; nervura central sulcada na face adaxial e saliente na face abaxial, de 10-20 pares de nervuras secundárias, nervura marginal formada por arcos incompletos, 0,5 $\mathrm{mm}$ da margem; pontuações translúcidas visíveis apenas em lupa, salientes em ambas as faces. Flores solitárias; pedúnculos castanho-amarronzados, $15 \mathrm{~mm}$ de compr., com indumento castanho-amarelado ou castanhoamarronzado e pontuações translúcidas; cálice fechado no botão abrindo-se irregularmente na antese, sépalas 4-5, 6-7 × 3-7 mm, indumento argênteo, sem pontuações translúcidas; pétalas 4-5, $13 \times 6 \mathrm{~mm}$, glabras, com pontuações translúcidas. Bagas globosas, não costadas, imaturas, $20 \mathrm{~mm}$ de diâm., com indumento castanho-amarelado; sépalas persistentes.

Material examinado: área 2, 31.X.2008, fl., M.F. Casali \& E.A. Costa Jr 143 (SORO); 2326'32.25"S, 47³5'35.49”'O, 22.XI.2012, A.T. Silva \& L.E.G.D. Nogueira 16 (SORO); 2326'32.57”S, 47³5'35.32”O, 22.XI.2012, fr., A.T. Silva \& L.E.G.D. Nogueira 17 (SORO); 2326'32.88''S, 47³5'35.24'O, 22.XI.2012, A.T. Silva \& L.E.G.D. Nogueira 20 (SORO); $23^{\circ} 25^{\prime} 33.75^{\prime}$ 'S, 47³6'0.26”O, 19.XII.2012, fr., A.T. Silva 25 (SORO); 2326’35.34”S, 47³6'2.83"O, 7.II.2013, A.T. Silva 46 (SORO).

Material adicional examinado: BRASIL, SÃO PAULO, Santo Antonio da Alegria, bairro do Baú, trilha do Morro, 10.XI.1994, fl., A.M.G.A. Tozzi \& A. Sciamarelli 94 (UEC).

Segundo Govaerts et al. (2008), a espécie ocorre em toda América Tropical e Subtropical. BFG (2015), confirmam a ampla ocorrência em todo território nacional, presente em todos os domínios vegetacionais, exceto campos sulinos.

Trata-se da espécie de Myrtaceae mais comum na FLONA Ipanema, ocorrendo em toda a área, com maior frequência em áreas abertas e menos comum em locais de mata fechada. Possivelmente, muitos indivíduos foram plantados por antigos moradores nas cercanias das edificações, visto que há indivíduos de grande porte ao redor das construções e locais de fácil acesso.

Psidium guajava pode ser reconhecida na área de estudo pelo seguinte conjunto de caracteres: 
tronco liso, tortuoso e nodoso, ramos novos quadrangulares ou retangulares e folhas coriáceas com face abaxial com mais de 10 pares de nervuras secundárias, muito salientes formando arcos.

\subsection{Psidium guineense Sw., Prodr. [O. P. Swartz]} 77. 1788.

Fig. 5e

Arbustos de ca. $1 \mathrm{~m}$ de alt.; ramos jovens acinzentados, indumento argênteo, ligeiramente achatado nas partes terminais, sem pontuações translúcidas; ramos adultos acinzentados, glabros. Folhas com pecíolos de 5-7 mm de compr., castanho-amarelados, com indumento palha, sem pontuações translúcidas; lâminas de 45-90 $\times$ 25-50 mm, obovais ou raramente elípticas; ápice cuspidado, atenuado ou arredondado, base cuneada; face adaxial glabra ou com esparso e curto indumento castanho-amarelado, e face abaxial com indumento palha, discolores, coriáceas; margem ligeiramente revoluta, plana; nervura central sulcada na face adaxial e saliente na face abaxial, de 7-9 pares de nervuras secundárias, nervura marginal em arcos completos ou incompletos, de 1-2 mm da margem; pontuações translúcidas visíveis apenas em lupa, salientes em ambas as faces. Flores solitárias; pedúnculos marrons, de 10-25 mm de compr., com indumento argênteo, sem pontuações translúcidas; cálice fechado no botão abrindo-se irregularmente na antese, sépalas 4-5, 6-9 × 3-6 mm, curto indumento argênteo e pontuações translúcidas; pétalas 4-5, $10 \times 6$ $\mathrm{mm}$, glabras, com pontuações translúcidas. Bagas globosas, não costadas, imaturas, 10 mm de diâm., com curto indumento argênteo distribuído de forma irregular; sépalas persistentes.

Material examinado: $23^{\circ} 26^{\prime} 11.77^{\prime}$ 'S, 4736'6.26”O, 17.II.2013, fr., A.T. Silva 36 (SORO); 2326'29.66”'S, 47³5'56.72”O, 7.II.2013, fr., A.T. Silva 47 (SORO).

Material adicional examinado: BRASIL, SÃO PAULO, Valinhos, Clube de Campo Valinhos, 8.XI.2009, fl., A.M.C. Costa 170 (UEC).

Segundo Govaerts et al. (2008), a espécie ocorre desde o México até a região meridional da América do Sul. Na FLONA Ipanema a espécie foi encontrada na orla da Floresta Estacional Semidecidual, entre o sopé do morro Araçoiaba e uma área de reflorestamento com espécies nativas do Brasil.

$\mathrm{Na}$ área em estudo $P$. guineense pode ser facilmente confundido com $P$. guajava, podendo ser reconhecida pelos seguintes caracteres vegetativos: pares de nervuras secundárias inferior a 10 e lâminas foliares de $45-90 \times 25-50 \mathrm{~mm}$, enquanto que $P$. guajava possui mais de 10 pares de nervuras secundárias e lâminas foliares de $60-130 \times 35-80 \mathrm{~mm}$.

\subsection{Psidium sp.}

Arvoreta de $2 \mathrm{~m}$ de alt.; ramos jovens castanho-amarelados, curto indumento ferrugíneo, cilíndrico nas partes terminais, sem pontuações translúcidas; ramos adultos castanho-amarelados, glabros. Folhas com pecíolos de 3-5 mm de compr., verde-claros, com esparso e curto indumento ferrugíneo, canaliculados, sem pontuações translúcidas; lâminas de 30-45 × 15-30 mm, obovais ou elípticas; ápice atenuado, base aguda ou atenuada; faces adaxial e abaxial glabra, porém, nas folhas novas pode haver curto indumento ferrugíneo ao longo da nervura central da face adaxial, discolores, cartáceas; margem revoluta na parte basal; nervura central levemente sulcada na face adaxial e saliente na face abaxial, de 14-18 pares de nervuras secundárias, nervura marginal em arcos, de 0,5-2,0 mm da margem; pontuações translúcidas visíveis a olho nu, salientes em ambas as faces. Flores e frutos não vistos.

Material examinado: Iperó, Floresta Nacional de Ipanema: $23^{\circ} 26^{\prime} 0.51^{\prime \prime S}, 47^{\circ} 36^{\prime} 39.36$ 'O, 27.IX.2012, A.T. Silva 1 (SORO).

Na FLONA Ipanema ocorre em local de afloramentos rochosos, no início da trilha da Pedra Santa, Floresta Estacional Semidecidual.

Psidium sp. foi encontrada em fase vegetativa e não foi possível sua identificação até espécie. Difere das demais espécies de Psidium da FLONA Ipanema por apresentar folhas cartáceas, com margem revoluta na base e pontuações translúcidas visíveis ao olho nu.

\section{Agradecimentos}

Agradecemos à Coordenação de Aperfeiçoamento de Pessoal de Nível Superior (CAPES), a concessão da bolsa de Mestrado. À professora Fiorella Fernanda Mazine Capelo, a orientação. Aos funcionários e professores do curso de Diversidade Biológica e Conservação da Universidade Federal de São Carlos campus Sorocaba. Aos curadores e funcionários dos herbários visitados. Aos funcionários da Floresta Nacional de Ipanema e Instituto Chico Mendes.

\section{Referências}

Albuquerque, G.B \& Rodrigues, R.R. 2000. A vegetação do Morro de Araçoiaba, Floresta Nacional de Ipanema, Iperó (SP). Scientia Forestalis 58: 145-159. 
Bataghin, F.A.; Barros, F. \& Pires, J.S.R. 2010. Distribuição da comunidade de epífitas vasculares em sítios sob diferentes graus de perturbação na Floresta Nacional de Ipanema, São Paulo, Brasil. Revista brasileira de Botânica 33: 501-512.

BFG. 2015. Growing knowledge: an overview of Seed Plant diversity in Brazil. Rodriguésia 66: 1085-1113.

Esposito-Polesi, N.P.; Rodrigues, R.R. \& Almeida, M. 2011. Anatomia ecológica da folha de Eugenia glazioviana Kiaersk (Myrtaceae). Revista Árvore 35: 255-263.

Fávero, O.A; Nucci, J.C. \& De Biase, M. 2007. Unidades de paisagem e zoneamento ambiental: subsídios para a gestão da Floresta Nacional de Ipanema, Iperó/SP. Revista Ra 'e ga 14:35-53.

Govaerts, R.; Sobral, M.; Ashton, P.; Barrie, F.; Holst, B.K.; Landrum, L.R.; Matsumoto, K.; Mazine, F.F.; Nic Lughadha, E.; Proença, C.; Soares-Silva, L.H.; Wilson, P.G. \& Lucas, E. 2008. World checklist of selected families: Myrtaceae. Disponível em $<$ http:// www.kew.org/wcsp/>. Acesso em 1 agosto 2013.

Instituto Brasileiro do Meio Ambiente e dos Recursos Naturais Renováveis (IBAMA). 2003. Plano de Manejo: Floresta Nacional de Ipanema, Iperó. Ministério do Meio Ambiente, Brasília. 44p.

Judd, W.S.; Campbell, C.S.; Kellogg, E.A.; Stevens, P.F. \& Donoghue, M.J. 2009. Sistemática Vegetal: um enfoque filogenético. $3^{\text {a }}$ ed. Artmed, Porto Alegre. $632 \mathrm{p}$.

Koch, I.; Cardoso-Leite, E.; Almeida, V.P.; Mazine, F.F.; Castello, A.C.D; Ferreira, L.C.; Kortz, A.R.; Kataoka E.Y.; Coelho, S. \& Mota, M.T. 2014. Plantas com flores e frutos das áreas de vegetação remanescentes do Município de Sorocaba. Biodiversidade do Município de Sorocaba, Sorocaba. Pp. 79-125.

Landrum, L.R. 1986. Campomanesia, Pimenta, Blepharocalyx, Legrandia, Acca, Myrrhinium and Luma. Flora Neotropica 45: 1-178.

Landrum, L.R. \& Kawasaki, M.L. 1997. The genera of Myrtaceae in Brazil: an illustrated synoptic treatment and identification keys. Brittonia 49: 508-536.

Leitão Filho, H.F. 1982. Aspectos taxonômicos das florestas do Estado de São Paulo. Silvicultura em São Paulo 16: 197-206.

Leitão-Filho, H.F. 1993. Ecologia da Mata Atlântica de Cubatão(São Paulo). Editora Unesp, São Paulo. 184p.
Lima, D.F.; Goldenberg, R. \& Sobral, M. 2011. O gênero Campomanesia (Myrtaceae) no estado do Paraná, Brasil. Rodriguésia 62: 683-693.

Lucas, E.J.; Harris, S.A.; Mazine, F.F.; Belsham, S.R.; Nic Lughadha, E.M.; Telford, A.; Gasson, P.E. \& Chase, M.W. 2007. Suprageneric phylogenetics of Myrteae, the generically richest tribe in Myrtaceae (Myrtales). Taxon 56: 1105-1128.

Lucas, E.J.; Matsumoto, K.; Harris, S.A.; Nic Lughadha, E.M.; Benardini, B. \& Chase, M.W. 2011. Phylogenetics, Morphology, and Evolution of the Large Genus Myrcia s. 1. (Myrtaceace). International Journal of Plant Sciences 172: 915-934.

Regalado, L.B. 2005. Contribuição ao gerenciamento da Floresta Nacional de Ipanema: o uso de base cartográfica digital na construção de um modelo alternativo ao plano de manejo. Tese de Doutorado em Ciências da Engenharia Ambiental - Escola de Engenharia de São Carlos. Universidade de São Paulo, São Carlos. 173p.

Ross, J.L.S. \& Moroz, I.C. 1997. Mapa Geomorfológico do Estado de São Paulo. Laboratório de Geomorfologia. Mapas e Relatório. Depto. Geografia (FFLCH USP)/ Laboratório de Cartografia Geotécnica e Geologia Aplicada (IPT)/ FAPESP, São Paulo. 64p.

Souza, V.C. \& Lorenzi, H. 2013. Botânica Sistemática: Guia Ilustrado para Identificação das Famílias de Fanerógamas Nativas e Exóticas do Brasil, Baseado em APG III. $3^{\text {a }}$ ed. Editora Plantarum, Nova Odessa. $768 \mathrm{p}$.

Stevens, P.F. 2012. Angiosperm Phylogeny Website. Version 12. Disponível em <http://www.mobot. org/MOBOT/research/APweb/>. Acesso em 8 agosto 2013.

Sytsma, K.J.; Litt, A.; Zjhra, M.L.; Pires, J.C.; Nepokroeff, M.; Conti, E. \& Wilson, P. 2004. Clades, clocks, and continents: historical and biogeographical analysis of Myrtaceae, Vochysiaceae, and relatives in the Southern Hemisphere. International Journal of Plant Sciences 165: 85-105.

Ziparro, V.B.; Guilherme, F.A.G.; Almeida-Scabbia, R.J. \& Morellato, L.P.C. 2005. Levantamento Florístico de Floresta Atlântica no Sul do Estado de São Paulo, Parque Estadual Intervales, Base Saibadela. Biota Neotropica5 (1). Disponível em <http://www.biol. ruu.nl./ palaeo/glossary/glos-int.htm $>$. Acesso em 5 maio 2014. 
